\title{
Germany: Financial Sector Assessment Program-Detailed Assessment of Observance on Eurex Clearing AG Observance of the CPSS-IOSCO Recommendations for Central Counterparties
}

This Financial Sector Assessment Program - Detailed Assessment of Observance on Eurex Clearing AG Observance of the CPSS-IOSCO Recommendations for Central Counterparties for Germany was prepared by a staff team of the International Monetary Fund as background documentation for the periodic consultation with the member country. It is based on the information available at the time it was completed in July, 2011. The views expressed in this document are those of the staff team and do not necessarily reflect the views of the government of Germany or the Executive Board of the IMF.

The policy of publication of staff reports and other documents by the IMF allows for the deletion of market-sensitive information.

\author{
Copies of this report are available to the public from \\ International Monetary Fund • Publication Services \\ $70019^{\text {th }}$ Street, N.W. • Washington, D.C. 20431 \\ Telephone: (202) 623-7430 • Telefax: (202) 623-7201 \\ E-mail: publications@imf.org Internet: http://www.imf.org
}

\section{International Monetary Fund Washington, D.C.}


FinANCIAL SECtor Assessment Program Update

\title{
GERMANY
}

Eurex Clearing AG ObSERVANCE OF THE CPSS-IOSCO RECOMMENDATIONS FOR CENTRAL COUNTERPARTIES

\section{DETAILED ASSESSMENT OF OBSERVANCE}

JULY 2011

\author{
INTERNATIONAL MONETARY FUND
}

MONETARY AND CAPITAL MARKETS DEPARTMENT 


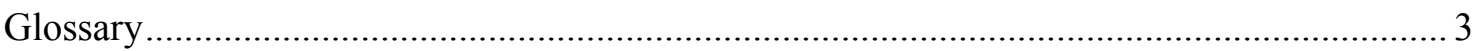

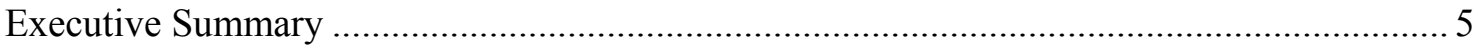

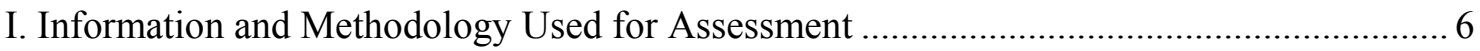

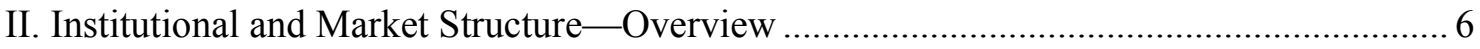

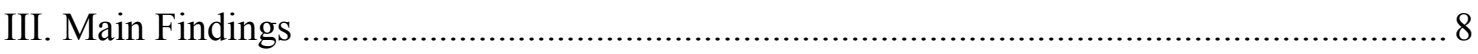

Tables

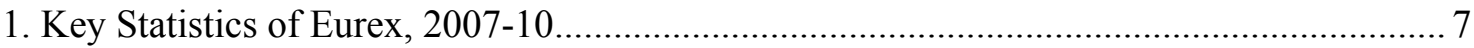

2. Detailed Assessment of Observance of Eurex Clearing AG............................................. 10

3. Summary of the Detailed Assessment of Observance of Eurex Clearing AG .................... 34

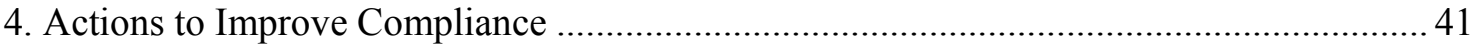

5. Further Recommended Actions............................................................................... 41

Figures

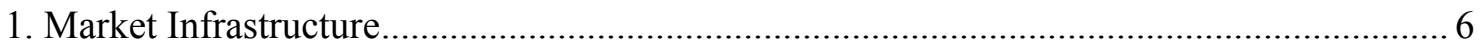

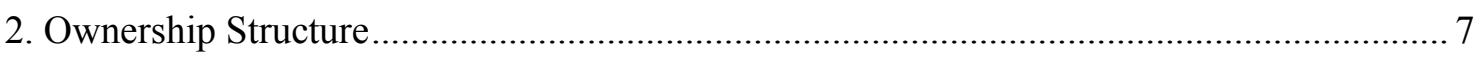




\section{GLOSSARY}

\begin{tabular}{|c|c|}
\hline $\mathrm{BCP}$ & Business Continuity Plan \\
\hline BaFin & Bundesanstalt für Finanzdienstleistungsaufsicht \\
\hline $\mathrm{BCM}$ & Business Continuity Management Policy \\
\hline $\mathrm{CCP}$ & Central Counterparty \\
\hline CDS & Credit default swaps \\
\hline CEBS & Committee of European Banking Supervisors \\
\hline CFTC & United States Commodities Futures Trading Commission \\
\hline $\mathrm{CHF}$ & Swiss francs \\
\hline CPSS & Committee on Payment and Settlement Systems \\
\hline CRD & Capital requirements directive \\
\hline CSD & Central securities depository \\
\hline CVaR & Conditional value at risk \\
\hline DCM & Direct Clearing Member \\
\hline DBG & Deutsche Börse Group \\
\hline DTB & Deutsche Termin Börse \\
\hline DTCC & Depository Trust and Clearing Corporation (DTCC) \\
\hline DVP & Delivery-versus-Payment \\
\hline EEA & European Economic Area \\
\hline EEC & European Commodity Clearing \\
\hline EEX & European Energy Exchange \\
\hline ESCB & European System of Central Banks \\
\hline Eurex & Eurex Clearing AG \\
\hline EUR & Euros \\
\hline FAC & Financial Accounting and Controls Department \\
\hline FiNMa & Swiss Financial Market Supervisory Authority \\
\hline FX & Foreign exchange \\
\hline FSA & United Kingdom Financial Services Authority \\
\hline GCM & General Clearing Member \\
\hline GBP & British pound \\
\hline ICSDs & International Central Securities Depositories \\
\hline IMF & International Monetary Fund \\
\hline IOSCO & International Organization of Securities Commission \\
\hline ISO & International Organisation for Standardisation \\
\hline $\mathrm{NCM}$ & Non-Clearing Member \\
\hline $\mathrm{MCO}$ & Multilateral Clearing Organization MCO \\
\hline MOF & Ministry of Finance \\
\hline MOJ & Ministry of Justice \\
\hline MOU & Memorandum of understanding \\
\hline OTC & Over-the-Counter \\
\hline RBM & Risk-Based Margining \\
\hline $\mathrm{RCCP}$ & Recommendation for Central Counterparties \\
\hline $\mathrm{ROCH}$ & Recognized Overseas Clearing House \\
\hline RSSS & Recommendation for securities Settlement Systems \\
\hline SEC & United States Securities and Exchange Commission \\
\hline SIX & Swiss Exchange Group \\
\hline
\end{tabular}


SNB Schweizerische (Swiss) National Bank

SREP Supervisory Review and Evaluation Process 


\section{EXECUTIVE SUMMARY}

Eurex Clearing AG (Eurex) observes the Committee on Payment and Settlement Systems (CPSS)-International Organization of Securities Commission (IOSCO) Recommendations for Central Counterparties (RCCPs). Eurex has a sound, transparent, and enforceable legal basis to address the legal risks related to its activities. It has developed a comprehensive and adequate risk management framework to address financial and operational risks. The default rules and procedures are clearly stated in its rules, which are available to its participants. Participants' assets as well as collaterals are safely kept in regulated national and international depositories, although there is legal uncertainty for client's assets portability, which is addressed by legislative proposals. Eurex uses central bank money for the cash settlement of most of its transactions. Eurex governance arrangements and composition of management, boards, and committees are clear and made publicly available.

Eurex is regulated and supervised as a bank, and all regulatory requirements are related to banking activities. The Federal Financial Supervisory Authority (Bundesanstalt für Finanzdienstleistungsaufsicht) (BaFin) does not fully observe the recommendation on regulation and oversight, as it has not defined any specific regulatory regime that covers Eurex CCP business. Furthermore, the Bundesbank does not have the legal basis to oversee Eurex as a financial market infrastructure.

The authorities provisionally evaluated the impacts of the draft CPSS/IOSCO Principles (expected to be finalized by end-2011) on Eurex activities, and it was concluded that the impact of the new principles on Eurex Clearing depends on the outcome of the current discussion. Nevertheless, it was expected that the new principles would not have a significant impact on Eurex, and it will be able to adjust to the new requirements as far as needed. 


\section{INFORMATION AND METHODOLOGY USED FOR ASSESSMENT}

1. The assessment of Eurex against the CPSS/IOSCO RCCP was undertaken in the context of the IMF's Financial Sector Assessment Program (FSAP) Update for Germany, January 17-February 3, 2011. ${ }^{1}$ Prior to the mission, Eurex conducted a comprehensive self assessment following the methodology of the RCCPs, which was published in 2004. The assessor also benefited from discussions with BaFin, Deutsche Bundesbank, Eurex senior management and staff, and some major participants in the system. The German authorities and the operator of the system have been very cooperative in providing supplemental information and organizing additional meetings to fulfill the assessment.

\section{InSTITUTIONAL AND MARKET STRUCTURE-OVERVIEW}

\section{Eurex provides central counterparty (CCP) services for several stock exchanges} and over-the- counter (OTC) transactions. It offers fully automated, electronic, and straight-through post trade services for both cash instruments and derivatives such as equities, bonds, repo, and energy products (Figure 1).

Figure 1. Market Infrastructure

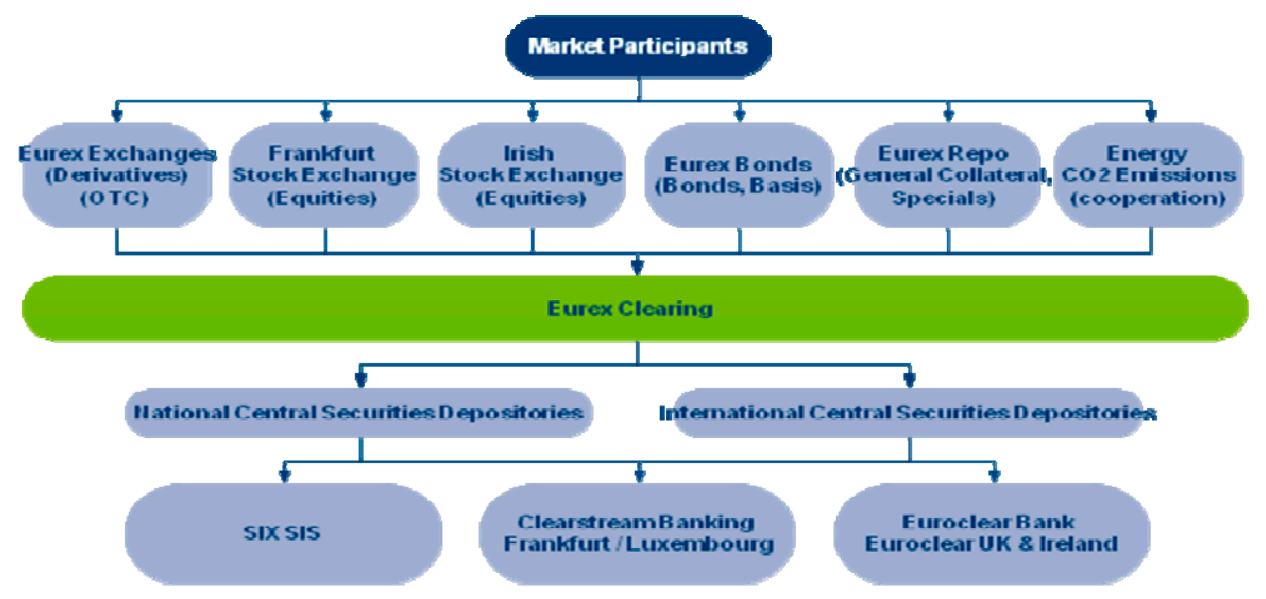

Source: Eurex.

3. Eurex was established in 1990 offering clearing services to Eurex predecessor, Deutsche Termin Börse (DTB). It is a wholly owned subsidiary of Eurex Frankfurt AG, which in turn is jointly owned by Deutsche Börse AG and SIX Swiss Exchange (Figure 2).

\footnotetext{
${ }^{1}$ The assessor was Elias Kazarian of the IMF's Monetary and Capital Markets Department.
} 


\section{Figure 2. Ownership Structure}

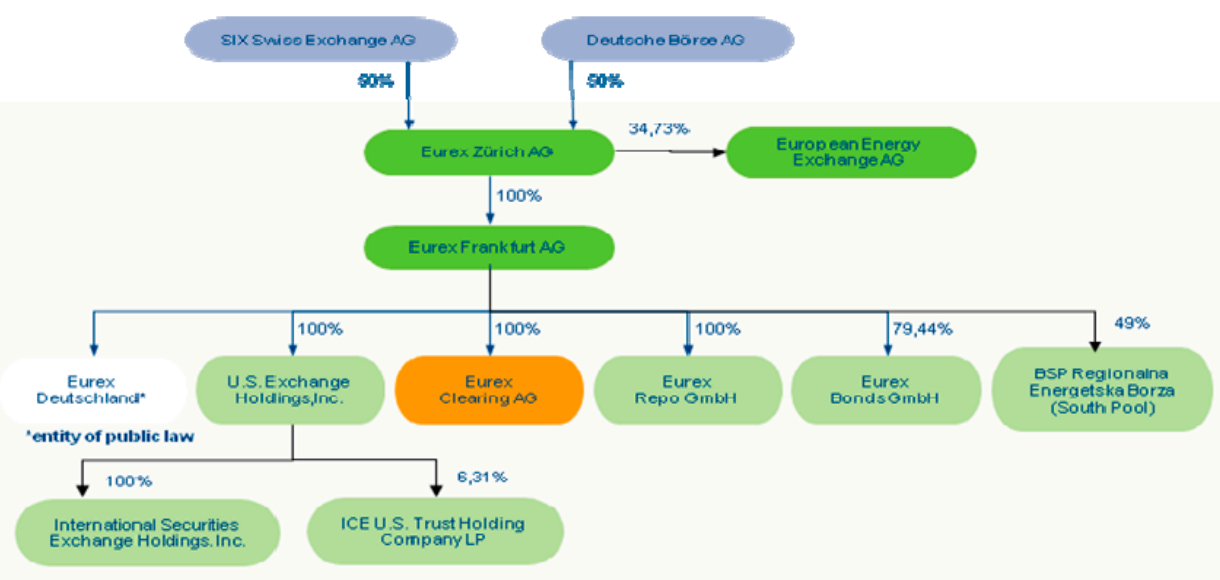

Table 1. Key Statistics of Eurex, 2007-10

\begin{tabular}{|c|c|c|c|c|c|}
\hline & 2006 & 2007 & 2008 & 2009 & 2010 \\
\hline \multicolumn{6}{|l|}{$\begin{array}{l}\text { 1.Number of transactions } \\
\text { (millions) }\end{array}$} \\
\hline 1.1 Equities & 73.48 & 109.98 & 129.15 & 94.23 & 96.45 \\
\hline 1.2 Debt instruments & 0.009 & 0.089 & 0.115 & 0.085 & 0.097 \\
\hline 1.3 Derivatives & $1,526.75$ & $1,899.80$ & $2,165.04$ & $1,687.16$ & $1,896.92$ \\
\hline Total & $1,600.24$ & $2,009.87$ & $2,294.31$ & $1,781.48$ & $1,993.47$ \\
\hline $\begin{array}{l}\text { 2. Value of transactions (EUR } \\
\text { billions) }\end{array}$ & $108,039.4$ & $127,156.4$ & $116,757.3$ & $80,525.9$ & $99,838.9$ \\
\hline $\begin{array}{l}\text { 3. Average daily value of } \\
\text { transactions (EUR billions) }\end{array}$ & 423.7 & 504.6 & 459.7 & 317.0 & 390.0 \\
\hline $\begin{array}{l}\text { 4. Peak value of transactions } \\
\text { (EUR billions) }\end{array}$ & 945.2 & $1,287.1$ & $1,110.3$ & 802.3 & 841.1 \\
\hline $\begin{array}{l}\text { 5. Number of clearing members } \\
\text { of which: }\end{array}$ & 119 & 118 & 109 & 117 & 128 \\
\hline 5.1 Foreign clearing members & 66 & 66 & 60 & 65 & 75 \\
\hline 6. Clearing fund (EUR millions) & 752 & 895 & 1,392 & 1,259 & 912 \\
\hline
\end{tabular}

4. Eurex is licensed as a credit institution and is regulated and supervised by BaFin. In conducting its oversight responsibilities, BaFin applies the RCCPs. Eurex is also subject to the Bundesbank's oversight. BaFin and the Bundesbank's statutory mandate to regulate and oversee Eurex is based on their banking supervisory capacity (German Banking Act). Both BaFin and Bundesbank have formal and extensive cooperation to monitor Eurex activities. 


\section{MaIn Findings}

\section{Legal framework (Rec. 1)}

5. Eurex clearing activities are governed by a consistent and solid set of laws, regulations, rules, and instructions. In particular, this legal framework supports the enforcement of transactions, netting procedures, protection of customer assets, and delivery versus payment (DVP) with finality. There are adequate rules for addressing the event of a participant default, including the effective use of collateral, and these rules can legally be enforced. The implementation of both the settlement finality and collateral directives provide a solid protection both in Germany and other European Economic Area (EEA) countries.

\section{Participation requirements (Rec. 2)}

6. Eurex access and exit criteria are well defined and publicly disclosed. Eurex requirements for participants' financial resources and operational reliability are defined according to membership category and the types of services selected by the participants. All members must be regulated entities and must have a minimum capital requirement. Eurex also reviews the external credit ratings of the applicants before approval and assesses participants' operational capability.

\section{Financial risk management (Rec. 3-6)}

7. Eurex has a comprehensive risk management framework composed of objectives, measures, and tools defined at the level of Eurex and that of the DBG. Eurex monitors its participants' exposure on a real time basis, and conducts intraday calls for margins. Eurex employs different tools to limit its exposures to potential losses from defaulting participants. Major measures include a high level of required capital, margin requirements, and contributions to the clearing fund. The levels of margins are verified via back testing and stress testing calculations. Eurex can also require additional financial resources/margins from participants in situations when unusual trading activity is detected. The stress testing policies, assumptions, and scenarios are discussed with market participants and the regulating authority, and mitigating actions are available on Eurex website. Eurex default procedures are clearly stated in the system's rules and published on its website. Eurex accepts highly liquid collaterals such as cash, government, and covered bonds.

\section{Custody and investment risks (Rec. 7)}

\section{Eurex securities and cash associated with its clearing activities are held in} national and international central securities depositories. Cash collateral is placed according to Eurex Treasury and Credit Policy, which describe standards for approving market counterparts and treasury limits. Some private banks are used for the deposit of noneuro currencies, generally in form of repos. Eurex investments in U.S. dollars (USD) are carried out through repo transactions, and the Bank of New York Mellon and JP Morgan Chase act as triparty agents. 


\section{Operational risk (Rec. 8)}

9. Eurex business continuity arrangements are developed at the level of the holding company, DBG, and covers all sites, networks control centers and business sites. At the DBG level, there is a Group Risk Management (GRM) that defines the overall objectives and monitors the overall risk profile of DBG, including a comprehensive Business Continuity Management (BCM) policy. The BCM policy ensures that the risk framework is implemented group-wise so that all risks are identified, centrally recorded, and systemically assessed. Contingency plans and back-up facilities are regularly tested with market participants and relevant parties, and maintained to ensure the resilience of Eurex.

\section{Money settlements (Rec. 9)}

10. Eurex uses both central bank money and private settlement bank for cash processing (margin and settlement). The central bank money is used for cash payments of euros (EUR) and Swiss francs (CHF), and for settlement in the euro area and Swiss markets. For cash payments of British pound (GBP), and USD as well as for global Eurobond settlement, private settlement banks, including the two International Central Securities Depositories (CSDs), Clearstream Banking, and Euroclear Bank, are used.

Physical deliveries (Rec. 10)

11. Eurex deliveries of securities are carried out in book-entry form (immobilized or dematerialized), and delivery obligations are fulfilled via book transfer. Eurex Clearing Conditions clearly define the responsibilities to deliver and receive securities from participants. Eurex delivery process is supported by a DVP and receive versus payment (DvP/RvP) settlement eliminating principal risk. A simultaneous booking is always given due to the functionality of the chosen settlement system of the CSD, which operates on DVP.

\section{Risks in links between central counterparties (Rec. 11)}

12. Eurex has one link with the European Commodity Clearing AG (ECC), which is located in Germany. The contractual relation is simultaneously extended by Eurex as a counterpart of the ECC and the clearing member. Eurex has specific rules and risk methodology for linked CCPs, aimed at minimizing the risk that all obligations cannot be performed in a timely manner. Both Eurex and ECC are regulated and supervised by BaFin. Both CCPs are designated payment systems according to Article 10 of the Settlement Finality Directive 98/26/EC, which provides legal protection to finality.

\section{Efficiency (Rec. 12)}

13. Eurex regularly reviews its pricing, service, and capacity levels. It performs periodic benchmarking studies with comparable CCPs in other European countries to assess its costs and fees. Eurex provides rebates to participants when their transaction volumes exceed some specified thresholds. An ongoing profit and loss analysis is conducted; the outcome is provided to the Executive Board of Eurex. Eurex states that, in the pricing of its clearing activities that are a part of other services, there is no cross subsidiary between different services and products of Eurex and those provided by other entities of the DBG. Nevertheless, Eurex applies higher prices to clear OTC transactions compared to exchange- 
traded transactions. Although such a policy has the merit that it encourages moving trade to exchanges, it is possible that the clearing fees for non-traded transactions are subsidizing the cost of clearing traded transactions.

\section{Governance (Rec. 13)}

14. Eurex is a wholly owned subsidiary of Eurex Frankfurt, which is owned by Eurex Zurich, and the latter is jointly owned by Deutsche Börse and SIX Swiss Exchange. Eurex governance arrangements and composition of the boards are clear and publicly available via the Eurex website. At its supervisory board, Eurex has representative from Deutsche Börse, market participants, and regulators (only as observers).

\section{Transparency (Rec. 14)}

15. Eurex discloses to its clearing members and other market participants, its rules, procedures, and policies on its website. These rules cover, among other things, governance issues, the rights and obligations of participants, procedures for handling risks, and fees for using its services. Also, important notices and information are posted on the website. Eurex has completed a comprehensive self-assessment following the RCCPs assessment methodology.

\section{Regulation and oversight (Rec. 15)}

16. Eurex is regulated and supervised by several authorities. In Germany, the main regulator is BaFin, which cooperates with Deutsche Bundesbank. As a global CCP, Eurex is also regulated and overseen by the Swiss Financial Market Supervisory Authority (FINMA)/ Swiss National Bank (SNB), as a recognized overseas clearing house (ROCH) by the United Kingdom Financial Service Authority (FSA), and as a Multilateral Clearing Organization by the United States Commodities Futures Trading Commission (CFTC) as well as by the United States Securities and Exchange Commission (SEC). Licensed as a credit institution and subject to the banking act, Eurex does not have a specific regime for its CCP activities, although BaFin has been using the overall risk management provision to require Eurex to meet the CPSS/IOSCO recommendations.

\section{Table 2. Detailed Assessment of Observance of the Eurex Clearing AG (Eurex) of the CPSS-IOSCO Recommendations for Central Counterparties}

\begin{tabular}{|l|l|}
\hline Recommendation 1. & $\begin{array}{l}\text { A CCP should have a well founded, transparent and enforceable legal } \\
\text { framework for each aspect of its activities in all relevant jurisdictions. }\end{array}$ \\
\hline Description & $\begin{array}{l}\text { Accessibility of the regulatory framework (Q1) } \\
\text { Laws, regulations, rules, procedures and contractual provisions governing the } \\
\text { operations and activities of Eurex clearing are public and readily accessible to } \\
\text { system participants on Eurex clearing AG website } \\
\text { http://www.eurexclearing.com/documents/regulations/clearing conditions en. }\end{array}$ \\
& $\begin{array}{l}\text { htm } \\
\text { Eurex Clearing AG's activities are governed and regulated by: }\end{array}$ \\
& - Kürgerliches Gesetzbuch (BGB) - Civil Code. \\
- Insolvenzordnung(InsO) - Insolvency Code. \\
- Solvabilitätsverordnung (SolvV) - Solvency regulation.
\end{tabular}




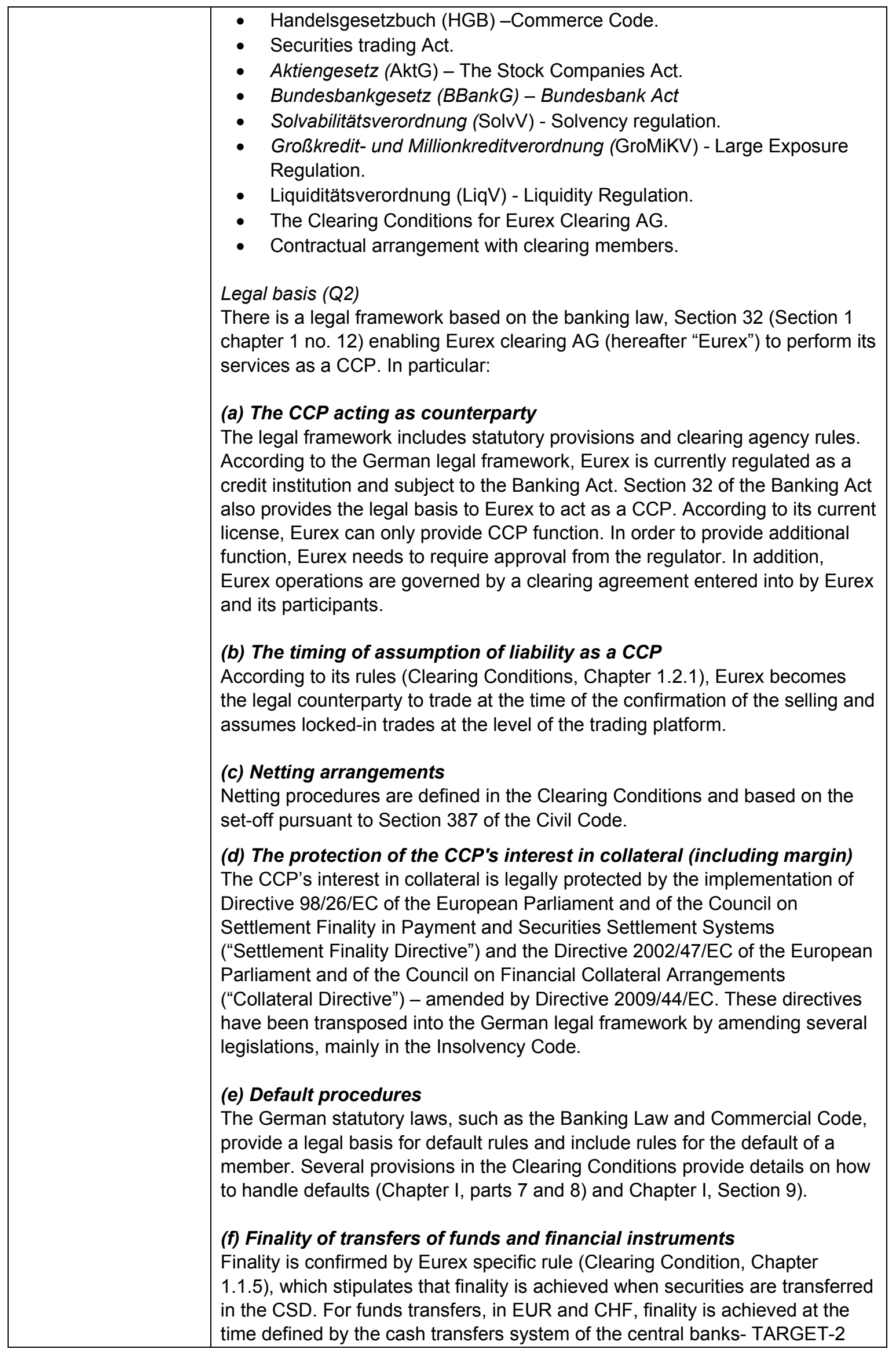




\begin{tabular}{|c|c|}
\hline & $\begin{array}{l}\text { and the Swiss payment system. Regarding the use of USD and GBP, Eurex } \\
\text { uses private banks, which provide intra-day confirmations of credit. } \\
\text { Enforceability of rules/procedures/contracts (Q3) } \\
\text { Enforceability is ensured as the rules and regulations are part of the contract } \\
\text { that is signed by the participants. The handling of default or insolvency of } \\
\text { Eurex participants, including the closing out of the participant's positions, is } \\
\text { regulated in the Clearing Conditions (Chapter I, parts } 7 \text { and } 8 \text { ). In addition, the } \\
\text { European Union legislation provides legal protection to the clearing activities } \\
\text { in the EEA, including the Finality and Collateral Directives. } \\
\text { The legal basis for the clearing links between Eurex and the linked clearing } \\
\text { houses are provided by the Clearing Conditions (Chapter I, number } 9.4 \text { ). The } \\
\text { clearing link agreements contain specific default rules including close-out } \\
\text { netting rules. } \\
\text { Cross-border activities (Q4) } \\
\text { There is a significant number of Eurex participants domiciled in other EEA } \\
\text { member states. Eurex has carried out legal analysis with regard to the } \\
\text { applicable insolvency law in the case of a participant's insolvency. } \\
\text { Within the EEA, the Finality Directive provides harmonized rules in each } \\
\text { member state, which states that "in the event of insolvency proceedings being } \\
\text { opened against a participant in a system, the rights and obligations arising } \\
\text { from, or in connection with, the participation of that participant shall be } \\
\text { determined by the law governing that system." } \\
\text { At present, Eurex does not have a remote participant domiciled outside the } \\
\text { EEA. Nevertheless, when such an applicant is submitted to Eurex, a legal } \\
\text { opinion on conflict of law will be prepared. Furthermore, independent of the } \\
\text { jurisdiction of the participants, all Eurex clearing members have to submit } \\
\text { themselves to the German jurisdiction once they sign the Eurex clearing } \\
\text { agreement. Thus, in case of any law suits between Eurex and its members } \\
\text { regarding obligations in the context of the clearing services, German laws will } \\
\text { primarily be applied. }\end{array}$ \\
\hline Assessment & Observed \\
\hline Comments & $\begin{array}{l}\text { In line with its license, Eurex is regulated as a credit institution with a single } \\
\text { purpose to provide clearing activity. The banking law and other legislations } \\
\text { provide a sound, transparent, and enforceable legal basis for each aspect of } \\
\text { its activities. } \\
\text { Eurex can change its clearing conditions without prior consultation or approval } \\
\text { by the relevant regulator and overseer, although in practice Eurex does } \\
\text { consult. It is recommended that the relevant authorities should require Eurex } \\
\text { to prior consult the authorities for any material changes of its clearing } \\
\text { conditions. This procedure would ensure a higher degree of legal safety, } \\
\text { public interest taken into account, and increase impartiality vis-à-vis its } \\
\text { participants. }\end{array}$ \\
\hline Recommendation 2 & $\begin{array}{l}\text { A CCP should require participants to have sufficient financial resources and } \\
\text { robust operational capacity to meet obligations arising from participation in the } \\
\text { CCP. A CCP should have procedures in place to monitor that participation } \\
\text { requirements are met on an ongoing basis. A CCP's participation } \\
\text { requirements should be objective, publicly disclosed, and permit fair and open } \\
\text { access. }\end{array}$ \\
\hline Description & $\begin{array}{l}\text { Sufficient financial resources and robust operational reliability (Q1) } \\
\text { Eurex financial and operational requirements for participants are established }\end{array}$ \\
\hline
\end{tabular}




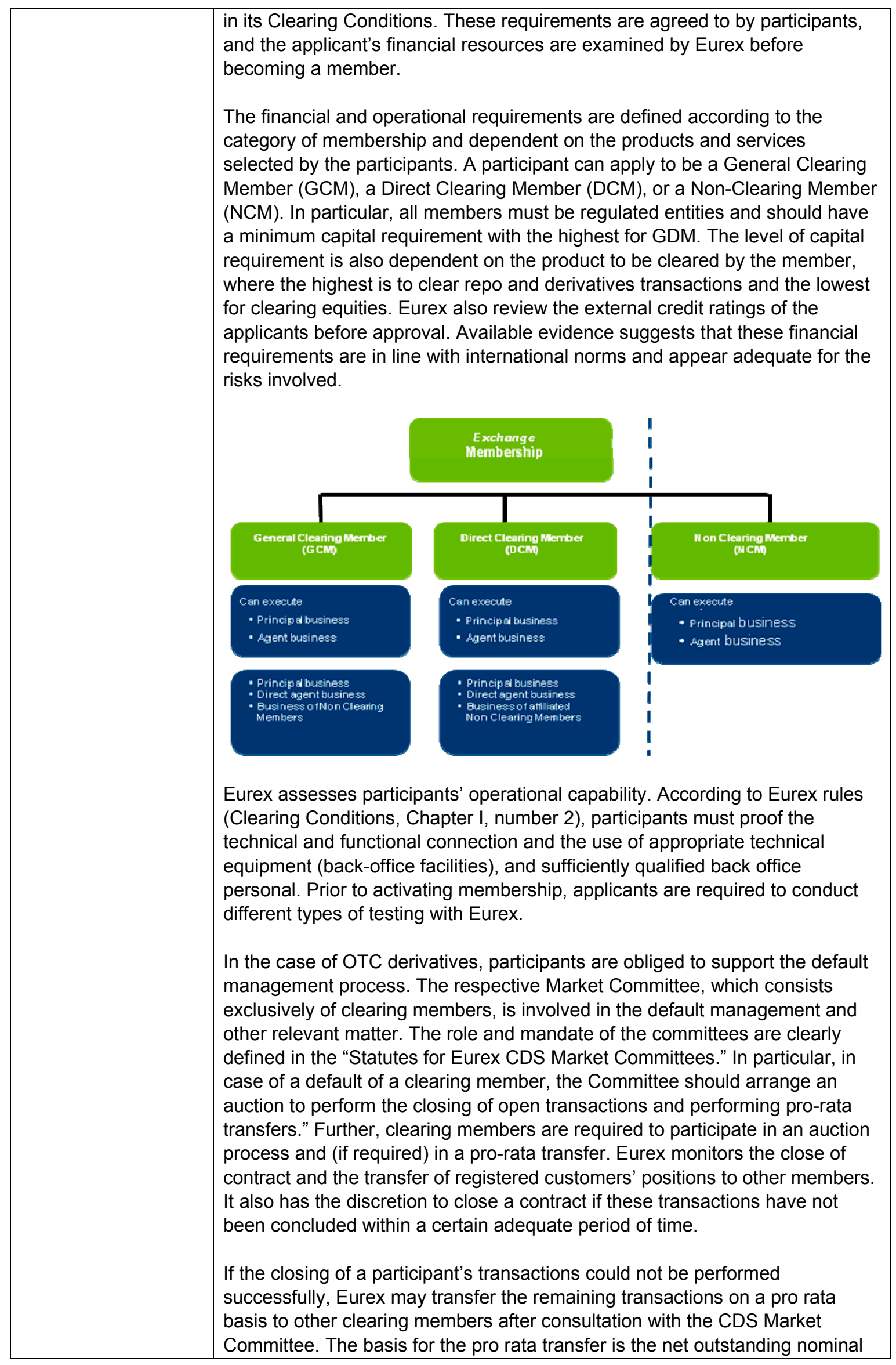


in the respective opposite transactions of the non-defaulting clearing member booked on their position accounts. Transfer will be based on the daily evaluation price of the previous business day determined by Eurex, to which a spread shall be added, or from which a spread shall be subtracted, depending on whether the remaining transactions are buy or sell transactions."

Monitor compliance with participation requirements (Q2)

Eurex has procedures in place to monitor the participants' requirements on an ongoing basis. Both the minimum liable equity capital and the fulfillment of the minimum clearing fund requirement are checked by the Member Services \& Admission Unit during the initial admission process. The size of the liable equity capital is monitored on a yearly basis, as all clearing members are required to report and prove their liable equity capital toward Eurex based on externally approved statement of annual report figures. In addition, the following measures are performed:

(a) Continuous intraday and overnight monitoring of the fulfillment of any payment and margin obligation.

(b) Monitoring of movements of share prices and credit spreads, where available.

Furthermore, the clearing members are obliged to inform Eurex if there are any changes to their participation requirements. Eurex carry out periodically a calibration of the liable equity capital requirement and the clearing Fund Requirement, considering the overall risk exposure of the single clearing member towards Eurex. The dynamic component for the liable equity capital requirement is calculated by 10 percent of a clearing member's 30 days and 250 days average total margin requirement. For the dynamic clearing Fund Component, 2 percent of a clearing member's 30 days and 250 days average total margin requirement are calculated. Both the liable equity requirement and the clearing fund requirement are determined by the highest single amount of the following components.

After having determined the liable equity capital requirement and the clearing fund requirement at the end of each quarter, a weekly check is carried out. In case of a shortfall in either liable equity capital requirement or clearing fund contribution, a clearing member has five days to fill the missing gap. If a clearing member does not provide the required additional collateral within the given five days, Eurex will call for immediate cash via direct debit authorization, which was provided by the participant in advance.

\section{Suspension and termination of participants' membership}

Eurex has rules for the termination and suspension of clearing licenses (Clearing Conditions, Chapter I, 2.4). A license for a GCM and DCM is terminated if:

(a) The clearing license has been granted on the basis of incorrect or incomplete information;

(b) The clearing member violates essential provisions of the Clearing Conditions or repeatedly violated other rules of the Clearing Conditions;

(c) The clearing member objects to an amendment of the Clearing Conditions; or

(d) Eurex has gained notice of the fact that measures against the clearing member have been ordered pursuant to provisions of the banking law or insolvency proceedings have been initiated and the concerned clearing member does not fulfill in whole or in part its obligations resulting from the clearing of its transactions or other obligations. Respective measures and proceedings under the law of the country in which the 


\begin{tabular}{|c|c|}
\hline & 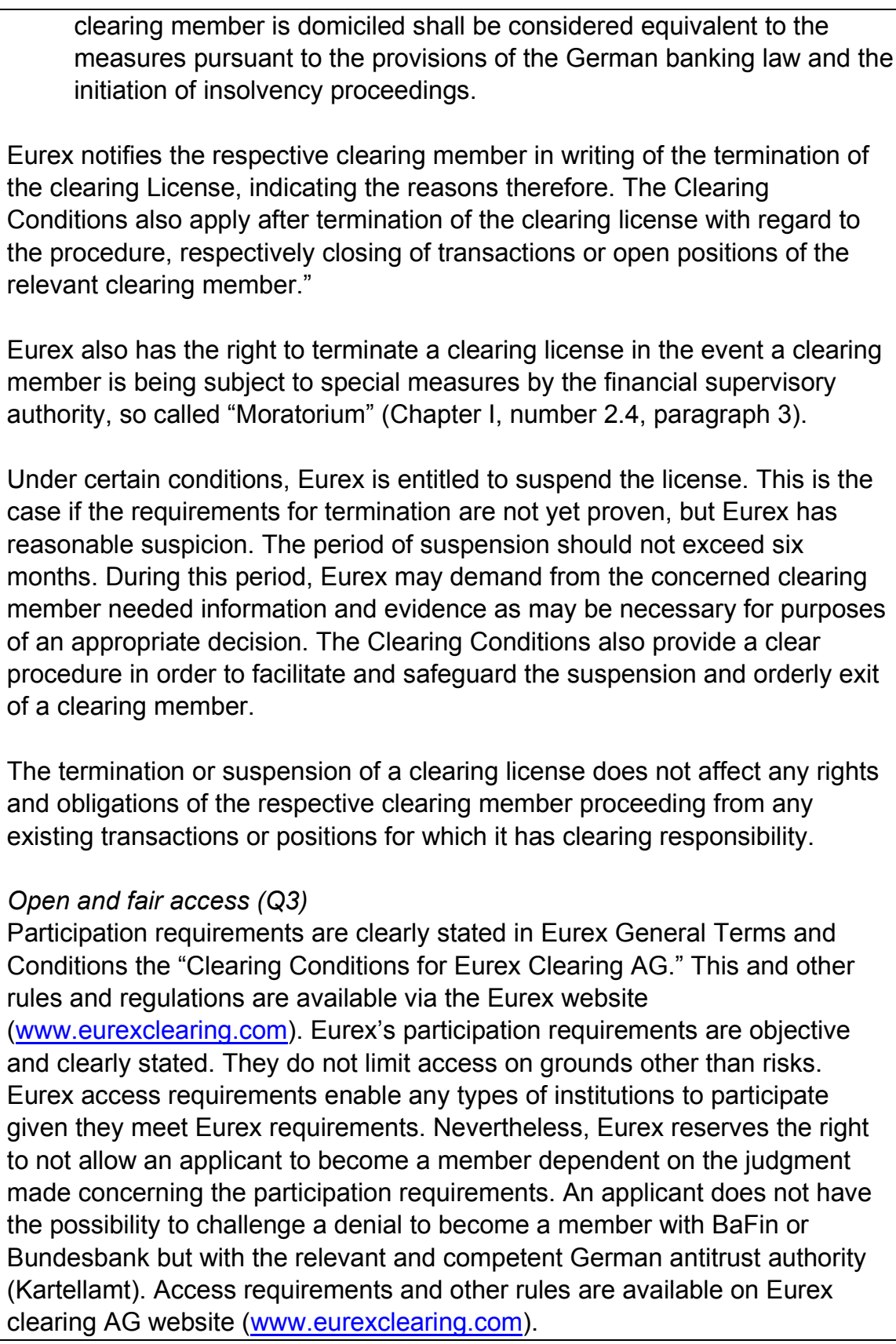 \\
\hline Assessment & Observed \\
\hline \multicolumn{2}{|l|}{ Comments } \\
\hline Recommendation 3. & $\begin{array}{l}\text { A CCP should measure its credit exposures to its participants at least once a } \\
\text { day. Through margin requirements, other risk control mechanisms or a } \\
\text { combination of both, a CCP should limit its exposures to potential losses from } \\
\text { defaults of its participants in normal market conditions so that the operation of } \\
\text { the CCP would not be disrupted and non-defaulting participants would not be } \\
\text { exposed to losses that they cannot anticipate or control. }\end{array}$ \\
\hline Description & $\begin{array}{l}\text { Measurement of exposures (Q1) } \\
\text { Eurex has a comprehensive risk management framework composed of } \\
\text { objectives, measures, and tools defined at the level of Eurex entity and } \\
\text { Deutsche Börse Group. This framework is reviewed and assessed on a } \\
\text { regular basis. The risk management objectives follow industry benchmark, } \\
\text { and relevant international standards. The risk management covers the entire } \\
\text { chain of a membership, including minimum capital, financial and technical }\end{array}$ \\
\hline
\end{tabular}




\begin{tabular}{|c|c|}
\hline & 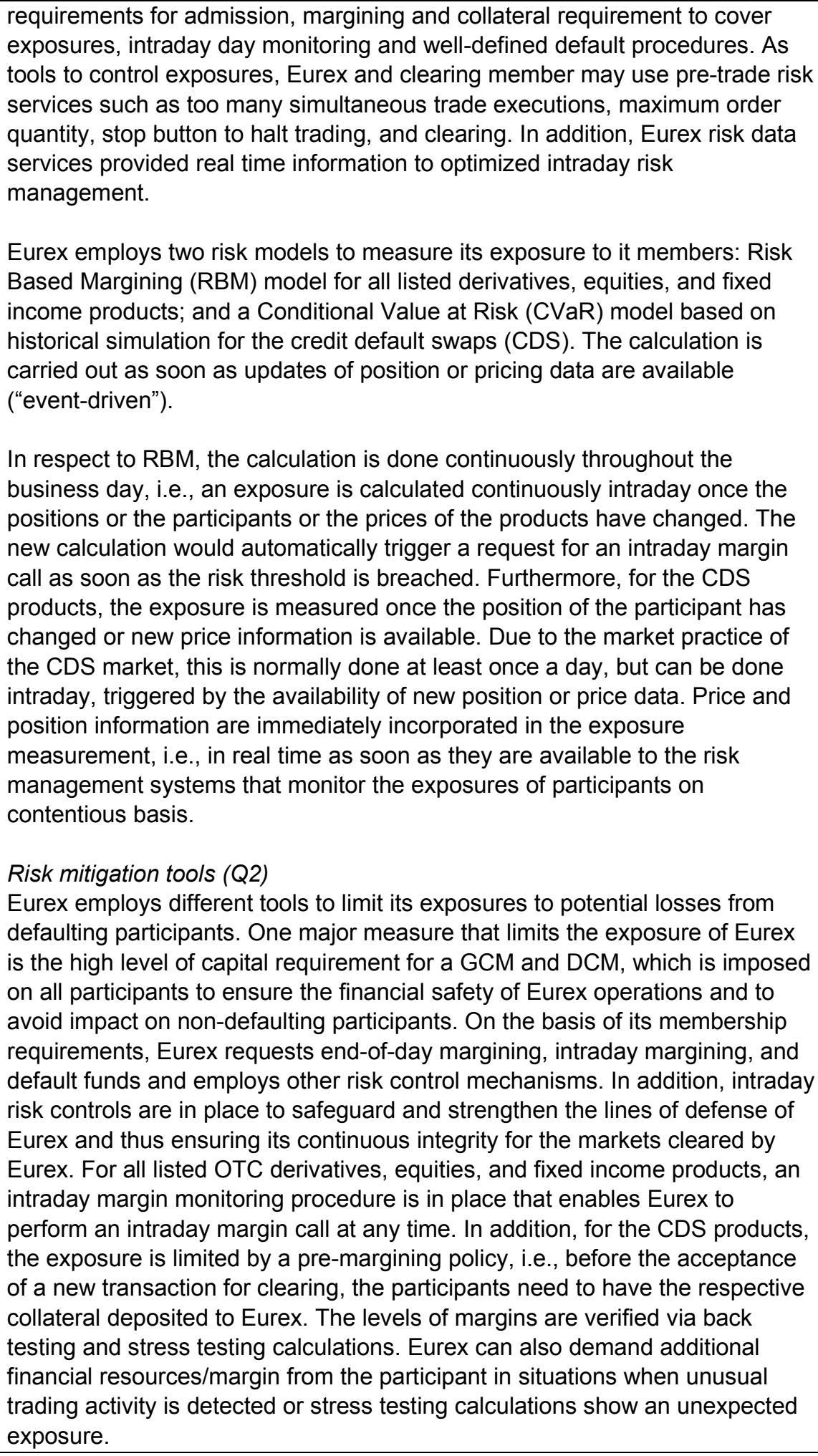 \\
\hline $\mathrm{A}$ & Observed \\
\hline \multicolumn{2}{|l|}{ Comments } \\
\hline Recommendation & $\begin{array}{l}\text { If a CCP relies on margin requirements to limit its credit exposures to } \\
\text { participants, those requirements should be sufficient to cover potential } \\
\text { exposures in normal market conditions. The models and parameters used in } \\
\text { setting margin requirements should be risk-based and reviewed regularly. }\end{array}$ \\
\hline
\end{tabular}




\begin{tabular}{|c|c|}
\hline Description & 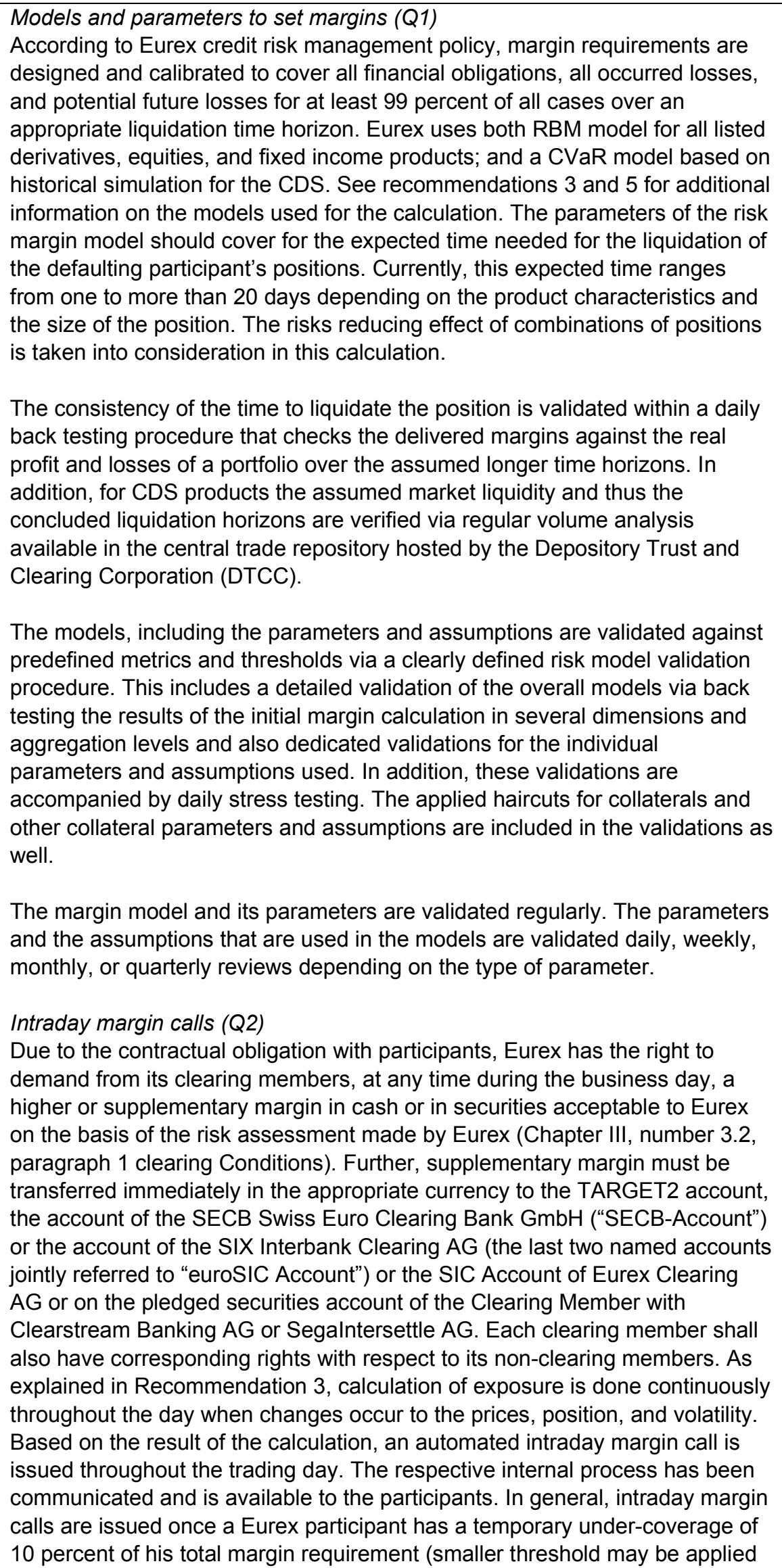 \\
\hline
\end{tabular}




\begin{tabular}{|c|c|}
\hline & $\begin{array}{l}\text { dependent on the risk assessment of the participant). } \\
\text { Assets accepted as margins and related haircuts (Q3) } \\
\text { As margin collateral, Eurex accepts securities (bonds and equities) that are } \\
\text { highly liquid, and of high credit quality, and cash (EUR, CHF, USD and GBP). } \\
\text { In order to meet high quality standards, the issuer must not be the clearing } \\
\text { member and the admissible portion of the bonds issues or the free float of } \\
\text { equities is limited. In general, all bonds collateral must be exchange-listed and } \\
\text { all EUR bond collateral must be eligible and of liquidity classes I-IV of the } \\
\text { European System of Central Banks (ESCB). All CHF bond collateral must be } \\
\text { eligible as repo of the Schweizerische Nationalbank (SNB). Equity collateral } \\
\text { must not exceed } 30 \text { percent of the margin requirement. Further details and the } \\
\text { full list of eligible instruments are available on the Eurex website; } \\
\text { http://www.eurexclearing.com/risk/parameters en.html. } \\
\text { On average, Eurex' collateral is composed of around } 15 \text { percent cash (around } \\
90 \text { percent in EUR) and } 85 \text { percent securities (nearly } 100 \text { percent bonds). The } \\
\text { securities collateral prices are evaluated at least daily. To be covered for a } \\
\text { potential decline in the value of the assets, haircuts on all securities and } \\
\text { currency haircuts are applied to all non-EUR cash collaterals. All haircuts are } \\
\text { calculated on a confidence level of } 99.9 \text { percent (i.e., } 99.9 \text { percent of the } \\
\text { respective price changes are below the applied haircut). }\end{array}$ \\
\hline Assessment & Observed \\
\hline \multicolumn{2}{|l|}{ Comments } \\
\hline Recommendation 5. & $\begin{array}{l}\text { A CCP should maintain sufficient financial resources to withstand, at a } \\
\text { minimum, a default by the participant to which it has the largest exposure in } \\
\text { extreme but plausible market conditions. }\end{array}$ \\
\hline Description & $\begin{array}{l}\text { Stress testing (Q1) } \\
\text { Eurex performs daily stress testing with extreme, but plausible market } \\
\text { conditions. It can be run on intraday basis when it is needed. Eurex has } \\
\text { defined coverage for the most extreme market conditions. This coverage } \\
\text { stipulates that obligations will be backed in at least } 999 \text { out of } 1,000 \text { events } \\
\text { with margin requirements and financial resources available. Eurex has a } \\
\text { stress test procedure in place that aims to verify that the financial resources } \\
\text { are sufficient to cover its risk exposure of defaulting clearing members in the } \\
\text { most extreme market conditions. Each clearing member's risk exposure is } \\
\text { stress tested against a comprehensive set of scenarios for all the product } \\
\text { groups that it clears. Scenarios include the worst historical observations that } \\
\text { have been experienced in each of the product groups as well as executive } \\
\text { management's expectations on worst potential future price movements. } \\
\text { Scenarios based on historical observations are mainly of two types: } \\
\text { a) Price movements across all product groups on specific crisis days. } \\
\text { b) Historically largest moves per product group independent of the } \\
\text { observation day. } \\
\text { The stress test is performed on the risk exposure of each clearing member, } \\
\text { and potential losses based on stress scenarios are compared to each } \\
\text { member's margin collateral. Losses beyond additional margin are then } \\
\text { compared to the clearing fund. }\end{array}$ \\
\hline
\end{tabular}



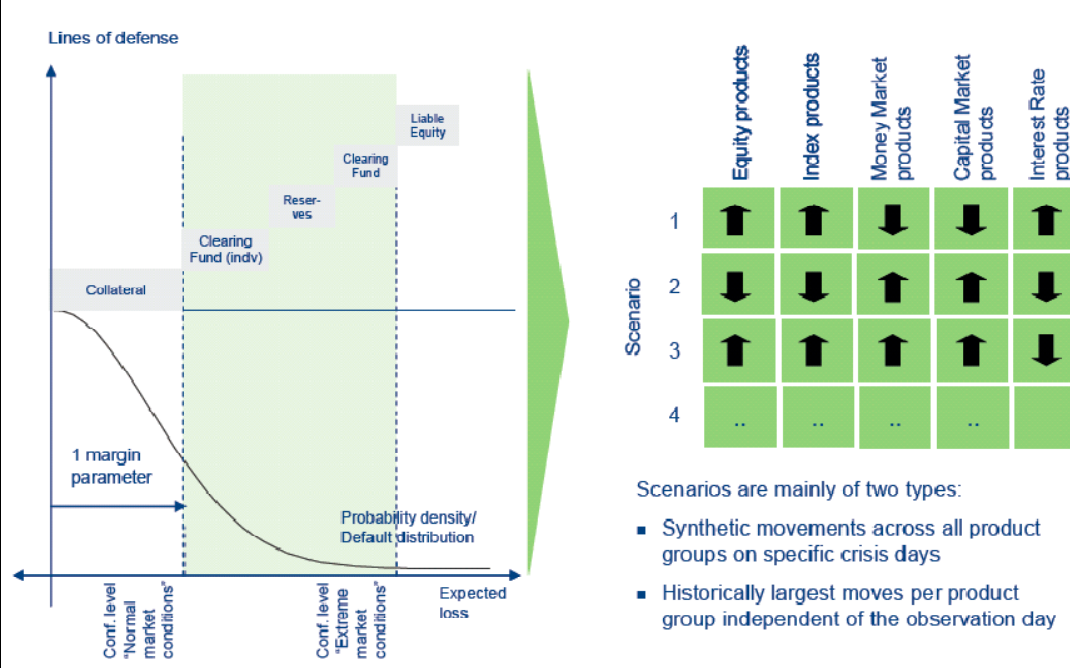

The stress scenarios are defined using dynamic parameters that are linked to the volatility of the underlying product, and thus by definition adjust automatically in case market volatility increases. The stress tests are performed daily and included in a daily and monthly stress testing reporting to the management. In parallel with the general risk model validations also the stress test scenarios and testing parameters (at least quarterly) are regularly reviewed and adjusted if required.

The analysis of the stress testing shows that the current resources would be sufficient to cover the simultaneous defaults of the five clearing members with the largest exposure.

Both the stress test scenarios and mitigating actions are available to the regulating authority. In addition the stress testing policy is available to the participants via the Eurex website. In a quarterly cycle the utilization of the financial resources is presented in an anonymous version to the Eurex Risk Committee, which is composed exclusively of clearing member.

Ability to draw on financial resources (Q2)

Eurex resources by means of lines of defense to handle default are:

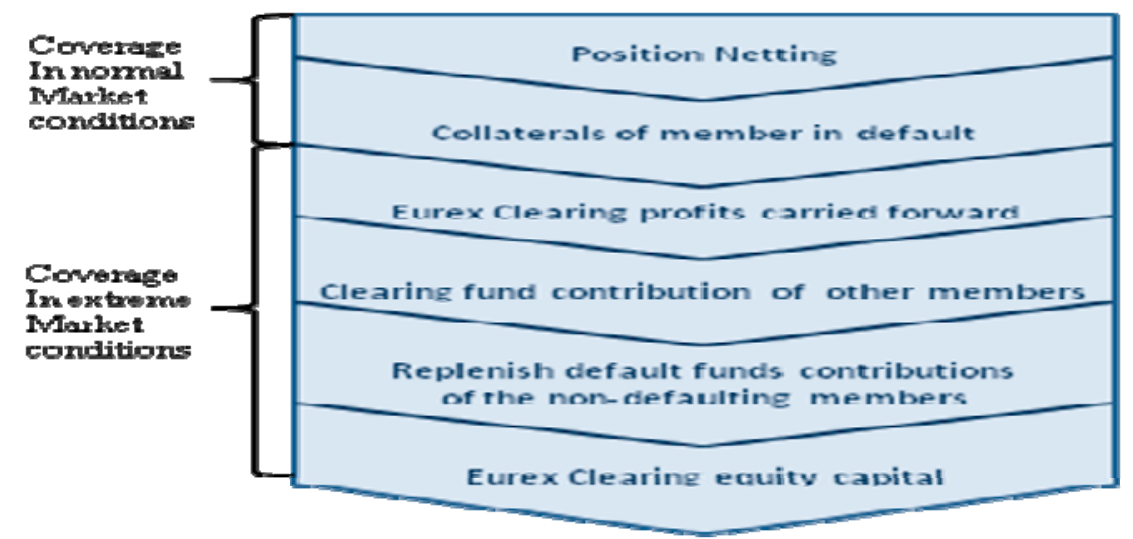

As of December 2010, Eurex financial resources are:

(a) EUR 1.5 billion in clearing Fund after taking into account haircuts.

(b) EUR 44 billion in collaterals held by Eurex. 


\begin{tabular}{|c|c|}
\hline & $\begin{array}{l}\text { (c) EUR } 5.5 \text { million in reserve fund. } \\
\text { (d) EUR } 110 \text { million in equity capital. } \\
\text { Eligible collaterals are cash, government and governmental agency bonds, } \\
\text { bank and corporate bonds for selected countries, and high liquid equities. The } \\
\text { collateral eligibility criteria are defined according to the level of credit, market, } \\
\text { and liquidity risks. } \\
\text { In the event that the resources are not sufficient to cover default, Eurex has } \\
\text { the right to request the non-defaulting clearing members to replenish the } \\
\text { clearing fund. } \\
\text { Immediate availability of financial resources (Q3) } \\
\text { Eurex resources to cover losses from a defaulting member are liquid and } \\
\text { immediately available. Collaterals (bonds/equities) are held on collateral } \\
\text { pledge accounts for the benefit of Eurex at eligible CSD in the EEA, hence } \\
\text { being immediately accessible for covering default losses. Also, the cash } \\
\text { collaterals are immediately available, as they have been already transferred to } \\
\text { the Eurex accounts (see above for the structure of Eurex cash accounts). The } \\
\text { accounts prohibit resources from being used for covering operating losses of } \\
\text { Eurex. } \\
\text { Eurex has access to intraday credit facility of the Eurosystem. Cash margins } \\
\text { placed by clearing members are to the largest extent placed overnight and are } \\
\text { thus to be classified as immediately available. }\end{array}$ \\
\hline Assessment & Observed \\
\hline \multicolumn{2}{|l|}{ Comments } \\
\hline Recommendation 6. & $\begin{array}{l}\text { A CCP's default procedures should be clearly stated, and they should ensure } \\
\text { that the CCP can take timely action to contain losses and liquidity pressure } \\
\text { and to continue meeting its obligations. Key aspects of the default procedures } \\
\text { should be publicly available. }\end{array}$ \\
\hline Description & $\begin{array}{l}\text { Definition of default and clarity of default procedures (Q1) } \\
\text { Eurex rules clearly states the circumstances that constitute a default or } \\
\text { insolvency case (Clearing Conditions, Chapter I, part 7). These rules allow } \\
\text { Eurex to control, manage, or close the positions of the defaulting member in a } \\
\text { way that ensures market integrity and Eurex security. Eurex also has the right } \\
\text { to transfer the customers' positions of the defaulting member to a } \\
\text { nondefaulting member. The waterfall model of Eurex lines of defense foresee } \\
\text { in the case of clearing member default that the defaulting member's assets } \\
\text { and collateral are liquidated. According to the clearing agreement between } \\
\text { Eurex and the clearing member, the clearing member confirms that he is the } \\
\text { owner/proprietor of the collaterals pledged with Eurex. Since according to } \\
\text { German Law, securities can, as a rule, only be pledged legally effective if the } \\
\text { pledgor owns the respective securities. Therefore, Eurex only accepts } \\
\text { propriety assets to be pledged by the clearing member and currently no } \\
\text { customer assets. } \\
\text { In the case of default, the first step undertaken by Eurex is to transfer } \\
\text { positions, especially client positions, to another clearing member within a set } \\
\text { period of time. Next step, Eurex will try to close out and settle the defaulting } \\
\text { member's open positions. For CSD products, Eurex may use an auction } \\
\text { process to liquidate the defaulter's position as a whole or in slots to the } \\
\text { nondefaulting members. Eurex also has the right to assign the remaining } \\
\text { positions pro rata to the non-defaulting clearing members. }\end{array}$ \\
\hline
\end{tabular}




\begin{tabular}{|c|c|}
\hline & 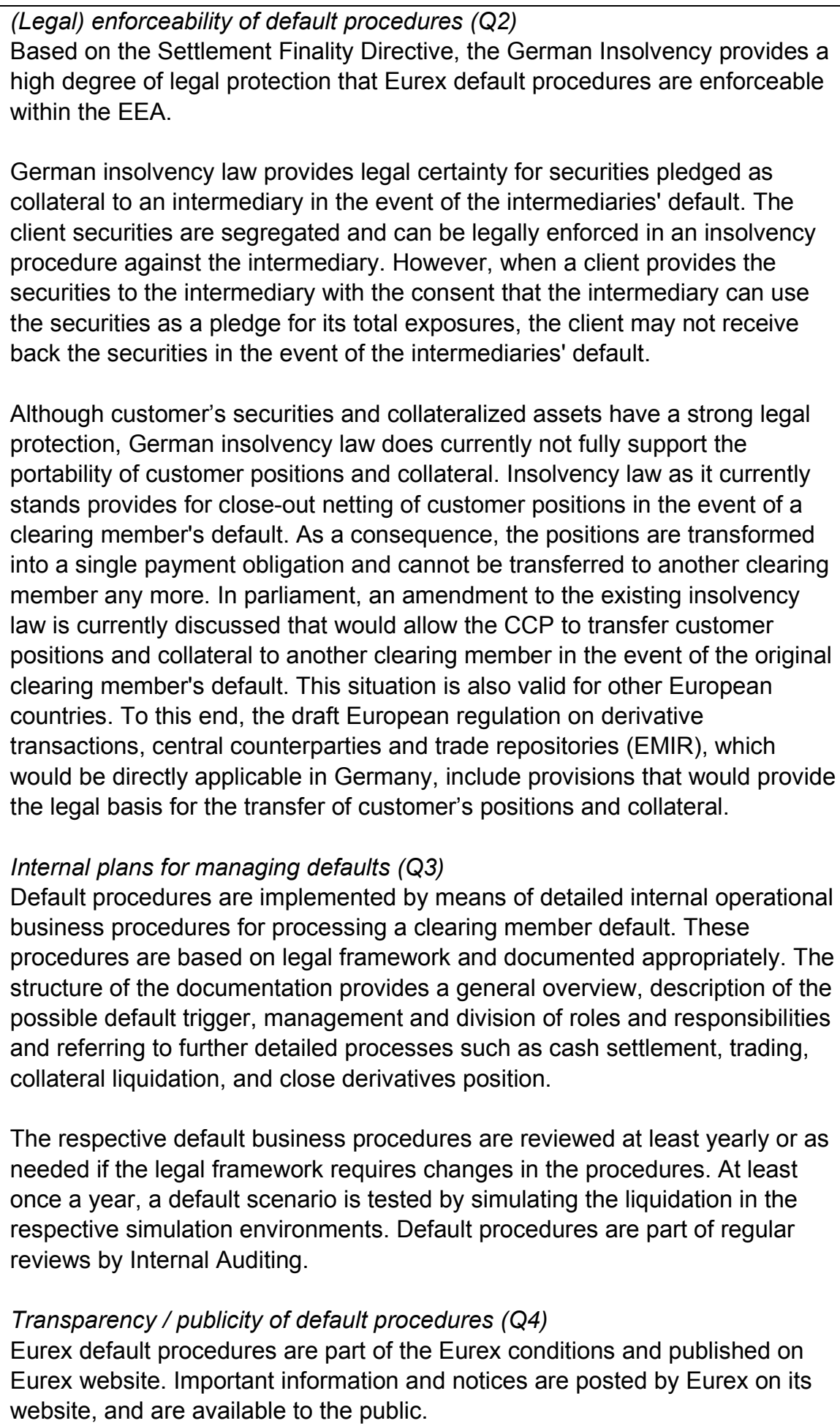 \\
\hline Assessment & Observed \\
\hline \multicolumn{2}{|l|}{ Comments } \\
\hline Recommendation 7. & $\begin{array}{l}\text { A CCP should hold assets in a manner whereby risk of loss or of delay in its } \\
\text { access to them is minimized. Assets invested by a CCP should be held in } \\
\text { instruments with minimal credit, market and liquidity risks. }\end{array}$ \\
\hline Description & $\begin{array}{l}\text { Monitoring of custody risk for CCP assets (Q1) } \\
\text { Securities pledged to Eurex by its participants are only deposited with CSDs } \\
\text { and international CSDs, which are supervised by national authorities. In }\end{array}$ \\
\hline
\end{tabular}


particular, securities are pledged in Clearstream Banking AG Frankfurt and SegalnterSettle AG. The participants' securities are held in dedicated accounts in the name of the participant, but pledged in favor of Eurex. These securities can only be withdrawn with the consent of Eurex.

The regulations in Germany and Switzerland provide an appropriate legal environment to ensure access to pledged securities in the case of insolvency of the clearing member. Settlement accounts with the ICSDs, Euroclear, and Clearstream Banking Luxembourg; and the CSDs Clearstream Banking Frankfurt and Euroclear United Kingdom and Ireland are used for securities settlement. At the end of the settlement day, no securities should be held in these accounts. Securities purchased in Eurex own repo transactions are held in Clearstream Banking (EUR), Credit Suisse (CHF), Bank of New York Mellon and JPMorgan Chase Bank (USD). Of course, Eurex has separate accounts for holding the pledged securities as collateral.

Eurex has in place processes and specialized staff to monitor the custodian banks, including:

(a) Daily monitoring of custodian's external ratings via reporting generated from Bloomberg.

(b) Annual credit reviews for custodians to assess their creditworthiness and to ensure that only liquid and solvent custodians are accepted. A major event (e.g., market shock) or a sudden change in custodian's credit quality may trigger a reassessment of the relationship. The sources used for the annual credit reviews are the annual reports, Bankscope, subscribed rating agencies reports (Fitch/Standard \& Poor's/Moody's), press, and web.

(c) Eurex assessment of these custodians against the CPSS/IOSCO recommendation 12 with regard to accounting practices and safekeeping/internal control procedures, regulated, and strong financial position.

Investments of CCP resources (Q2)

Cash collateral is placed according to Eurex Treasury and Credit Policy, which describes standards for approving market counterparts and treasury limits. The credit and treasury policies are reviewed annually and amended if necessary.

According to this policy, Eurex investment should be, to the extent possible, in the form of bilateral or triparty repo. For triparty repo, Clearstream Banking S.A., Bank of New York Mellon, and JP Morgan Chase act as triparty agents. Only residual balances are placed uncollateralized with commercial banks under credit limits approved by the Credit Section independent from the treasury. The Credit Section has the authority to approve investments within the limits approved by the Eurex Executive Board (Vorstand). Any amount exceeding the credit authority requires an exceptional approval by the Board.

Eligibility criteria for repo collateral include a minimum rating of AA- / Aa3. Since the outset of the financial crisis, only bonds representing sovereign risk are eligible. With regard to credit risk, eligible counterparts are required to have an external credit rating equal or above 'A-' with Fitch/Standard \& Poor's and 'A3' with Moody's, whereby the lowest rating applies. Any exception must be approved by the Eurex Executive Board.

Eurex Credit Section monitors its market counterparts in the following ways: (a) Daily monitoring of external credit ratings of market counterparts (report 


\begin{tabular}{|c|c|}
\hline & $\begin{array}{l}\text { generated from Bloomberg). } \\
\text { (b) Monthly reporting to the Eurex Executive Board, Treasury Department } \\
\text { and Group Risk Management via "Monthly Credit Report", which gives } \\
\text { an overview about new/existing market counterparts and treasury limits, } \\
\text { ratings, and treasury limits changes. } \\
\text { (c) Annual credit assessments and if necessary in case of a major event. } \\
\text { Any negative change in the quality of a counterpart may trigger a reduction or } \\
\text { cancellation of its treasury limit. } \\
\text { Eurex is not allowed to invest its own capital or margin in its own securities or } \\
\text { those of its parent company. } \\
\text { Concentration limits (Q3) } \\
\text { Investments may only be conducted under counterparty limits approved by the } \\
\text { Credit Section. In its assessment, it takes into account both the credit } \\
\text { worthiness of market counterparts as well as the total exposure of Deutsche } \\
\text { Börse Group toward counterparties in order to avoid any concentration of } \\
\text { credit risk. The investments of own liquidity and received cash collateral is } \\
\text { done with a variety of counterparts to avoid concentration risk. In addition, } \\
\text { Eurex concentration risk is limited by the Large Exposure Rules of the Capital } \\
\text { Requirements Directive since Eurex is also licensed as a bank. }\end{array}$ \\
\hline Assessment & Observed \\
\hline \multicolumn{2}{|l|}{ Comments } \\
\hline Recommendation 8. & $\begin{array}{l}\text { A CCP should identify sources of operational risk and minimize them through } \\
\text { the development of appropriate systems, controls and procedures. Systems } \\
\text { should be reliable and secure, and have adequate, scalable capacity. } \\
\text { Business continuity plans should allow for timely recovery of operations and } \\
\text { fulfillment of a CCP's obligations. }\end{array}$ \\
\hline Description & $\begin{array}{l}\text { Identification and management of operational risk (Q1) } \\
\text { The Eurex risk management framework is governed by policies and } \\
\text { procedures defined both at the level of Eurex and of Deutsche Börse Group } \\
\text { (DBG). At the level of Eurex, risk identification and management is done by } \\
\text { the Risk Design Unit and the Clearing and Risk Operations Unit. The main } \\
\text { focus of the former is to identify for example, the financial risk related to } \\
\text { products and collaterals, while the later monitors the risks associated with } \\
\text { Eurex's daily activities, including clearing operation and data management } \\
\text { issues. } \\
\text { At DBG, there is a Group Risk Management (GRM) that defines the overall } \\
\text { objective and monitors the overall risk profile of DBG. It ensures that the risk } \\
\text { framework is implemented group-wise so all risks are identified, centrally } \\
\text { recorded, and systemically assessed. The GRM's function is independent of } \\
\text { the operational areas, reporting to the executive management. } \\
\text { The operational risk for the entire group is defined as the risk of loss resulting } \\
\text { from inadequate or failed internal processes, staff and system or from external } \\
\text { events. The quantification of the risk is performed on a regular basis using } \\
\text { Value at Risk methodology. It relies on the use of internal and external } \\
\text { operational risk events, as well as scenarios. } \\
\text { Eurex IT is completely outsourced to Deutsche Börse Systems AG. Some } \\
\text { functions, such as the hosting of the website, are outsourced to the Swiss } \\
\text { Exchange (SIX) Group. All contracts have automatic prolongation clauses and } \\
\text { offer sufficient flexible rights to Eurex to cancel the contract in case the need }\end{array}$ \\
\hline
\end{tabular}


arises. Outsourcing relations are monitored according to the requirements of the German Banking Act in conjunction with BaFin's Minimum Requirements for Risk Management (MaRisk). There is a risk classification done at the time of the outsourcing and an annual review of those services classified as material from a risk perspective. This is carried out by the so-called outsourcing coordinator. This function is outsourced to Clearstream Banking AG. The monitoring results are presented to the Executive Management Board. Despite this centrally coordinated process to supervise and monitor outsourcing relations, the business owner of an outsourced serviceregardless of the regulatory classification-remains responsible to constantly monitor the service quality and the fulfillment of the service provider's obligations.

Contingency plans and back-up facilities (Q2)

The DBG has developed and implemented a comprehensive Business Continuity Management (BCM) policy, which defines the organizational roles and responsibilities, and the guiding principles to ensure operational resilience. The BCM arrangements also address the unavailability of systems, workspace, suppliers, and the loss of significant numbers of staff in order to ensure the continuity of the critical operations even in cases of catastrophe scenarios. The Group Risk Management Unit, which reports to the Executive Management, is responsible for the overall coordination and monitoring of Eurex preparedness to deal with incidents and crises.

The general Recovery Time Objective (RTO) within Eurex is set to four hours, which applies to systems, workspace, staff, and supplier unavailability, although recovery can be achieved quicker dependent on the incident. There are two geographically separated IT processing sites. The systems are clustered between the two data centre and load balanced in normal operation mode with continuous full data synchronization (real-time data mirroring). All types of components are redundant between the two data centers in each location and actively used for production. In case of an incident in one data centre, an automatic failover mechanism ensures that all processing is taken over instantly by the second data centre. The data centers are operated remotely as "dark rooms" requiring no onsite staff. Further, exclusively dedicated alternate facilities exist to provide office space for critical staff in the event their normal office location would become unavailable. The alternate office facilities are fully equipped and networked to both data centers are operational at all times.

The business continuity plan (BCP) is regularly reviewed on a six-monthly basis and are tested at least annually. Eurex has adopted a comprehensive and ambitious BCM testing approach to simulate situations as close as possible to real life. A simulation exercise is carried out annually with market participants. Plans and arrangements are validated against the following criteria:

(a) Functional effectiveness, validate that they are technically functioning.

(b) Execution ability, ensure that staff are familiar and knowledgeable in their execution.

(c) Recovery time, confirm that they can be executed within the defined recovery time objective.

In addition, certain BCM arrangements are used in production on a daily or routine basis (e.g., clustered systems, shift roster, and remote operations). Any issues are reported and resolved including any potential adjustments to operations. 


\begin{tabular}{|c|c|}
\hline & $\begin{array}{l}\text { Adequate management controls and periodic independent audit (Q3) } \\
\text { Operational reliability is regularly reviewed by senior management. All } \\
\text { relevant processes are audited periodically depending on their risk } \\
\text { assessment rating; "high" rated processes are audited annually, and } \\
\text { "medium" and "low" rated risk areas are audited every two or three years, } \\
\text { respectively. The Internal Audit Section, which is responsible for the audit, } \\
\text { submits its internal audit report to the executive board. No major incident } \\
\text { occurred last year. An external audit of the business continuity plan is already } \\
\text { carried out yearly. The annual audit of the yearend figures includes an audit of } \\
\text { the risk management systems of banks (including the German CCPs) as the } \\
\text { auditor also has to assess whether the minimum requirements regarding the } \\
\text { business continuity plan are met. (See section } 25 \text { a chapter } 1 \text { Nr.3 and section } \\
29 \text { of the Banking Act. } \\
\text { Availability and scalability of the system (Q4) } \\
\text { There was not a single complete failure of Eurex system in } 2010 \text {. In one } \\
\text { event, the system was available with delay because of missing input data. No } \\
\text { financial transaction data were lost. On average the system was available for } \\
99.95 \text { percent. } \\
\text { Capacity plans for the key systems are in place and regularly monitored and } \\
\text { reported to management. Stress tests in respect to loaded trades are } \\
\text { executed in a performance test environment. Eurex can process } 80 \text { percent } \\
\text { above peak processing volume. }\end{array}$ \\
\hline Assessment & Observed \\
\hline \multicolumn{2}{|l|}{ Comments } \\
\hline Recommendation 9. & $\begin{array}{l}\text { A CCP should employ money settlement arrangements that eliminate or } \\
\text { strictly limit its settlement bank risks, that is, its credit and liquidity risk from } \\
\text { the use of banks to effect money settlements with its participants. Funds } \\
\text { transfers to a CCP should be final when effected. }\end{array}$ \\
\hline Description & $\begin{array}{l}\text { Use of central bank money (Q1) } \\
\text { Eurex uses both central bank money and private settlement bank for cash } \\
\text { processing (margin and settlement). The central bank money, via TARGET-2 } \\
\text { and Swiss SIX payment systems, is used for cash payments for EUR and } \\
\text { CHF and for settlement in the German and Swiss markets. For cash } \\
\text { payments of GBP and USD, as well as, for Eurobond settlements, private } \\
\text { settlement banks, including the ICSDs Clearstream Banking and Euroclear } \\
\text { Bank are used. } \\
\text { Finality of transfers (Q2) } \\
\text { The finality for the settlement in central bank money for the EUR and CHF is } \\
\text { achieved in TARGET-2 and the Swiss payment system SIC is protected by } \\
\text { the Settlement Finality Directive and by the Swiss Banking Law (which } \\
\text { adopted parts of the Settlement Finality Directive), respectively. Barclays } \\
\text { Bank is used to settle GBP-denominated transactions. Finality is achieved } \\
\text { intraday. For transactions in USD, Citibank and JPMorgan bank are used. } \\
\text { Confirmation of the settlement is provided intraday. In all currencies, intra-day } \\
\text { confirmations of credit are provided by the settlement agent. Laws of the } \\
\text { relevant jurisdictions support the provisions of transfers and finality. } \\
\text { Criteria for selection of settlement banks (Q3) } \\
\text { Eurex applies strict criteria for the selection of private settlement agents. } \\
\text { Eligible agents must have an external credit rating equal or above 'A-' by } \\
\text { Fitch/Standard \& Poor's and 'A3' by Moody's, whereas the lowest rating }\end{array}$ \\
\hline
\end{tabular}




\begin{tabular}{|c|c|}
\hline & $\begin{array}{l}\text { applies. The Credit Section monitors these agents on a regular basis and also } \\
\text { undertakes an annual credit review to assess their creditworthiness and to } \\
\text { ensure their liquidity and solvency. } \\
\text { Monitor distribution of exposures among settlement banks (Q4) } \\
\text { Clearstream relies on two private agent banks for the settlement of USD } \\
\text { transactions. Eurex monitors its exposures between these two banks and tries } \\
\text { to avoid any concentration. For GBP transactions, the amounts are currently } \\
\text { considerably low and only one settlement agent bank is used. }\end{array}$ \\
\hline Assessment & Observed \\
\hline Comments & $\begin{array}{l}\text { Eurex relies on a few banks for the settlement of foreign exchange (FX) } \\
\text { denominated transactions, which exposures it to settlement risk. Access to } \\
\text { central bank account would enhance the integrity of the settlement process. } \\
\text { To this end, in 2008, Eurex applied for an account with the Federal Reserve } \\
\text { Bank of New York but no positive access decision has been taken since then. } \\
\text { Eurex uses central bank money for a broad range of products, e.g., the } \\
\text { collections of margins, the settlement of German equities, and the settlement } \\
\text { of bonds and repos. Nevertheless, as most banks hold their fixed income } \\
\text { portfolios in the ICSDs (i.e., Clearstream Luxembourg and Euroclear Bank } \\
\text { Brussels), contracts based on these fixed income securities are settled in } \\
\text { commercial bank money in those ICSDs. This applies to bond and repo } \\
\text { transactions carried out on the trading platforms Eurex Bonds and Eurex } \\
\text { Repo. } \\
\text { To further reduce settlement risk, Eurex may consider to settling in central } \\
\text { bank money and/or increasing the number of settlement agent banks for FX } \\
\text { currencies. }\end{array}$ \\
\hline Recommendation 10. & $\begin{array}{l}\text { A CCP should clearly state its obligations with respect to physical deliveries. } \\
\text { The risks from these obligations should be identified and managed. }\end{array}$ \\
\hline Description & $\begin{array}{l}\text { CCP obligations for physical delivery (Q1) } \\
\text { Eurex deliveries of securities are carried out in book-entry form (immobilized } \\
\text { or dematerialized) and delivery obligations are fulfilled via book transfer. } \\
\text { Eurex Conditions clearly define its responsibilities to deliver and receive } \\
\text { securities from participants. } \\
\text { DVP of mitigation of principal risks (Q2) } \\
\text { Eurex enters into trades and becomes the buyer for the seller and the seller to } \\
\text { the buyer. Eurex delivers the securities to the buyer after it is received from } \\
\text { the seller. This process is supported by a DvP/RvP settlement eliminating } \\
\text { principal risk. A simultaneous booking is always given due to the functionality } \\
\text { of the chosen settlement system of the CSD, although all the relevant CSDs } \\
\text { settle on DVP. } \\
\text { Liquidity, storage and delivery (other than principal) risks (Q3) } \\
\text { The risk of money settlement for the deliveries is covered first by the rule of } \\
\text { DvP/RvP. Second, cash obligations are covered by Eurex RBM. Storage risks } \\
\text { do not occur as all securities are usually held in safe custody in CSDs and } \\
\text { Eurex delivers them to the buyer in the moment Eurex receives them from the } \\
\text { seller. All risks affecting deliveries are assessed by risk management in real } \\
\text { time. }\end{array}$ \\
\hline Assessment & Observed \\
\hline Comments & \\
\hline
\end{tabular}




\begin{tabular}{|c|c|}
\hline Recommendation 11. & $\begin{array}{l}\text { CCPs that establish links either cross-border or domestically to clear trades } \\
\text { should evaluate the potential sources of risks that can arise, and ensure that } \\
\text { the risks are managed prudently on an ongoing basis. There should be a } \\
\text { framework for cooperation and coordination between the relevant regulators } \\
\text { and overseers. }\end{array}$ \\
\hline Description & $\begin{array}{l}\text { Sources of risks in links and compliance with RCCPs (Q1) } \\
\text { Eurex has currently one link with the European Commodity Clearing AG } \\
\text { (ECC), located in Leipzig, Germany. ECC is a subsidiary of the European } \\
\text { Energy Exchange (EEX), the leading European energy trading platform. ECC } \\
\text { is supervised by BaFin, and designated as a payment system according to } \\
\text { Article } 10 \text { of the Settlement Finality Directive 98/26/EC. Eurex has a sub-CCP } \\
\text { relationship with the ECC. In the case a counterpart is clearing transactions } \\
\text { conducted at the EEX via Eurex. Eurex simultaneously steps into the } \\
\text { transaction in addition to the EEC. The contractual relationship is } \\
\text { simultaneously extended by Eurex as a counterpart of the ECC and the } \\
\text { clearing member. Eurex has specific rules for linked CCP in its clearing } \\
\text { conditions. This is done to minimize the risk that all obligations cannot be } \\
\text { performed in a timely manner. } \\
\text { Legal support for links (Q2) } \\
\text { There is a Clearing Link Agreement between Eurex and the ECC that define } \\
\text { the rights and obligations between Eurex and the ECC. Since both CCPs are } \\
\text { located in Germany, the German jurisdiction will be applied and no potential } \\
\text { conflict of law would arise. Contractual rules governing the linked systems, } \\
\text { and governing the link itself, are submitted to the regulatory authorities for } \\
\text { review. } \\
\text { Ongoing monitoring of operational, liquidity and credit risk (Q3) } \\
\text { Before entering into a link, risks are evaluated (including due diligence or } \\
\text { other analysis/measures as seen fit) according to a specific link methodology. } \\
\text { Once a link is implemented and is operational, the risks associated with the } \\
\text { link are evaluated daily. } \\
\text { Co-operative (cross-border) oversight on links (Q4) } \\
\text { Both Eurex and the ECC are regulated and supervised by the BaFin. Both } \\
\text { CCPs are designated systems according to Article } 10 \text { of the Settlement } \\
\text { Finality Directive } 98 / 26 / E C \text {. }\end{array}$ \\
\hline Assessment & Observed \\
\hline \multicolumn{2}{|l|}{ Comments } \\
\hline Recommendation 12. & $\begin{array}{l}\text { While maintaining safe and secure operations, CCPs should be cost-effective } \\
\text { in meeting the requirements of participants. }\end{array}$ \\
\hline Description & $\begin{array}{l}\text { Procedures to control risks and pricing (Q1) } \\
\text { Eurex has in place procedures to control its operational costs. All budgets are } \\
\text { reviewed and approved by management. The Financial Accounting and } \\
\text { Controls (FAC) Department issues on a monthly basis, a set of financial } \\
\text { reports that are distributed to executive management and certain line } \\
\text { managers. These reports include comparison of budgets with actual and } \\
\text { previous year's figures. They are prepared following the IFRS commercial } \\
\text { format. A forecast for the entire year is also produced and revised periodically; } \\
\text { additionally a rolling forecast has been implemented. } \\
\text { Eurex states that the prices of its clearing activities may be a part of other } \\
\text { services, but according to Eurex management, there is no cross-subsidiary } \\
\text { between the services and product of Eurex and those provided by other }\end{array}$ \\
\hline
\end{tabular}




\begin{tabular}{|c|c|}
\hline & 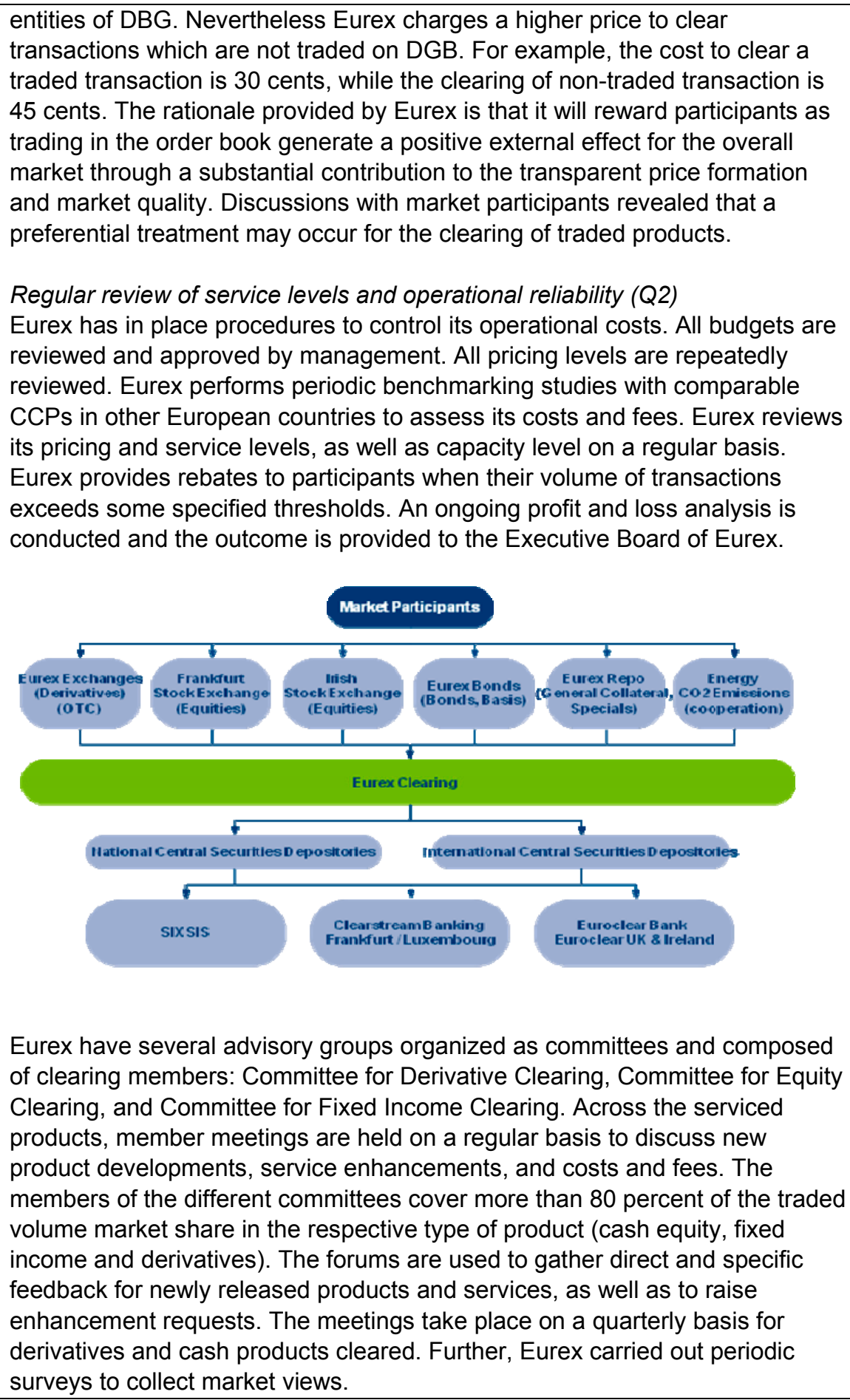 \\
\hline Assessment & Observed \\
\hline Comments & $\begin{array}{l}\text { Eurex applies higher prices to clear OTC transactions compared to exchange- } \\
\text { traded transactions. Eurex's argument for this policy is to promote the move of } \\
\text { OTC transactions to the exchange. Although such a policy has its merit to } \\
\text { move trade to trade platforms, it cannot be excluded that there is a } \\
\text { preferential treatment to clear traded transactions compared to the clearing of } \\
\text { OTC transactions. }\end{array}$ \\
\hline Recommendation 13. & $\begin{array}{l}\text { Governance arrangements for a CCP should be clear and transparent to fulfill } \\
\text { public interest requirements and to support the objectives of owners and } \\
\text { participants. In particular, they should promote the effectiveness of a CCP's }\end{array}$ \\
\hline
\end{tabular}




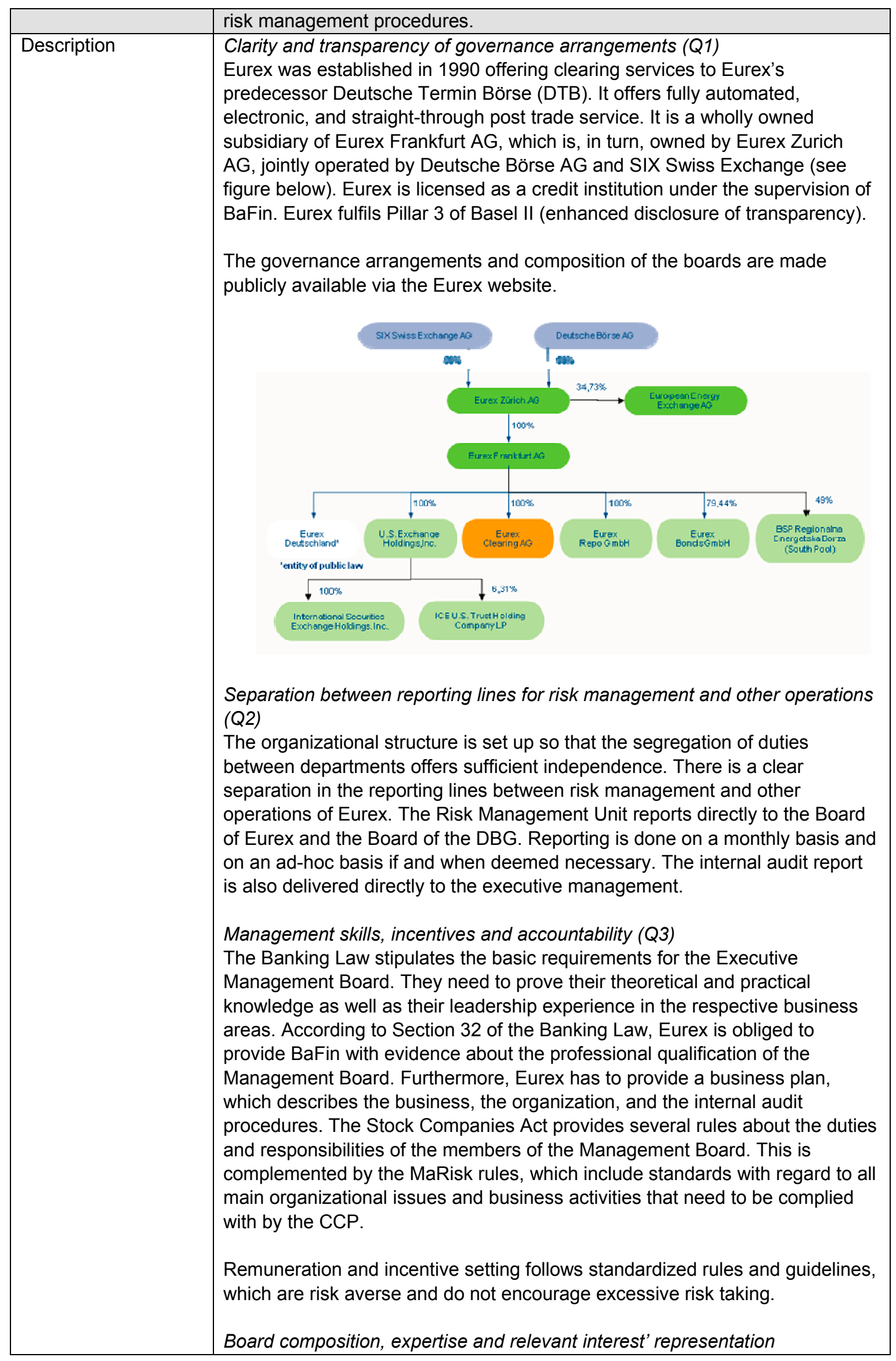




\begin{tabular}{|c|c|}
\hline & 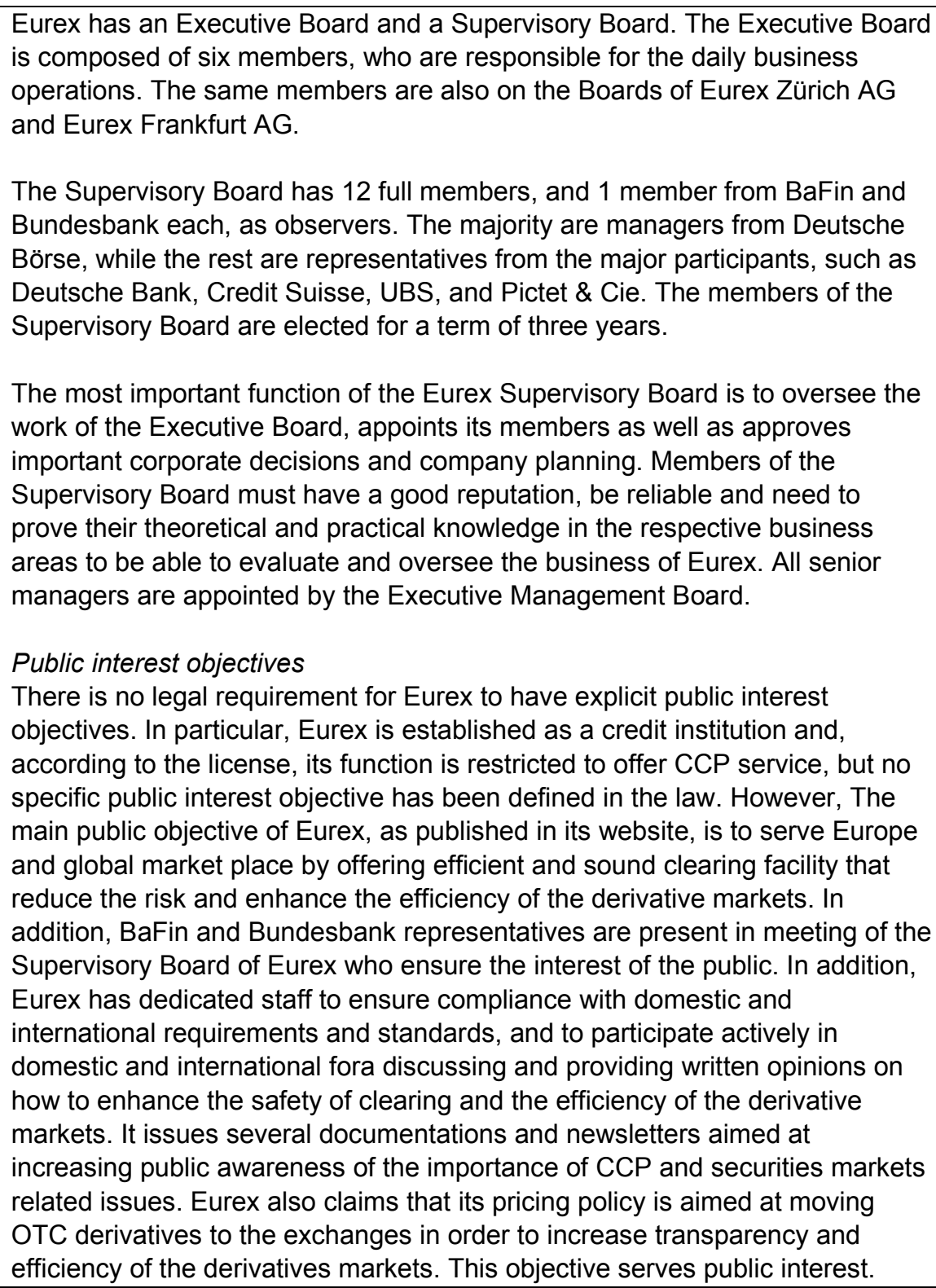 \\
\hline Assessment & Observed \\
\hline Com & $\begin{array}{l}\text { Eurex governance arrangements are clear and transparent, and publicly } \\
\text { available via the Eurex website. These arrangements also reflect the public } \\
\text { interest requirements and support the objectives of owners and participants. } \\
\text { Eurex should increase the number of independent board members taking into } \\
\text { account the interests of small and medium- sized clearing members. } \\
\text { Due to the crucial role of Eurex in the German financial market, BaFin may } \\
\text { explore the possibility to define explicit public interest objective to Eurex such } \\
\text { as to facilitate prompt, efficient, and sound clearing of securities transactions. }\end{array}$ \\
\hline Recommendation 14. & $\begin{array}{l}\text { A CCP should provide market participants with sufficient information for them } \\
\text { to identify and evaluate accurately the risks and costs associated with using } \\
\text { its services. }\end{array}$ \\
\hline Description & $\begin{array}{l}\text { Disclosure of risk management information (Q1) } \\
\text { Eurex discloses to its clearing members and other market participants its } \\
\text { rules, procedures, and policy on its website. These rules cover, among other }\end{array}$ \\
\hline
\end{tabular}




\begin{tabular}{|c|c|}
\hline & $\begin{array}{l}\text { things, governance issues, procedures for handling risks, the rights and } \\
\text { obligations of participants, and the costs of using its services. Also important } \\
\text { notices and information are posted on the website. } \\
\text { Eurex discloses the circumstances it accepts trades for clearing and thus } \\
\text { assumes exposure as a central counterparty. The legal basis of its activities } \\
\text { "Clearing Conditions" is also available online. } \\
\text { In addition, Eurex discloses to its members information on the risk } \\
\text { methodologies used (i.e., Risk Based Margining-scenario based matrix } \\
\text { approach and historical simulation), risk parameters, and other calculations } \\
\text { (e.g., detailed risk scenario calculations). Assessment of risks and costs are } \\
\text { publicly distributed on a periodic basis (for example, parameters; margin, and } \\
\text { haircuts). } \\
\text { Disclosure of quantitative information on its clearing, netting, and setting } \\
\text { activities is ensured within the DBG's annual report, revaluated statistics, and } \\
\text { the performance ("running") of the settlement activities. } \\
\text { Accessibility of information (Q2) } \\
\text { All relevant information is made public via the Eurex website in German and } \\
\text { English. } \\
\text { Completion and disclosure of the answers to the key questions of RCCPs } \\
\text { (Q3) } \\
\text { To ensure compliance with IOSCO Recommendations for Central } \\
\text { Counterparties, Eurex has been reviewed by internal auditing three times in } \\
\text { the past (2004, 2005, and 2008). The assessment performed in } 2008 \text { was } \\
\text { made available to the public. A review of the answers to the key questions } \\
\text { relating to these recommendations is being performed for the first time and } \\
\text { will be reviewed and published annually from here on. }\end{array}$ \\
\hline Asse & Observed \\
\hline \multicolumn{2}{|l|}{ Comments } \\
\hline Recommendation 15 & $\begin{array}{l}\text { A CCP should be subject to transparent and effective regulation and } \\
\text { oversight. In both a domestic and an international context, central banks and } \\
\text { securities regulators should co-operate with each other and with other } \\
\text { relevant authorities. }\end{array}$ \\
\hline Description & $\begin{array}{l}\text { Effective regulation and oversight (Q1) } \\
\text { Eurex is regulated and supervised by several authorities. In Germany, the } \\
\text { main regulator is BaFin, which cooperates with Deutsche Bundesbank to } \\
\text { monitor Eurex's ongoing activities. As a global CCP, Eurex is also subject to } \\
\text { the regulation and oversight by FINMA/SNB, by the FSA as a recognized } \\
\text { overseas clearing house (ROCH), and by the U.S. Commodities Futures } \\
\text { Trading Commission (CFTC) as a Multilateral Clearing Organization (MCO) as } \\
\text { well as by the U.S. Securities and Exchange Commission (SEC). } \\
\text { Eurex is licensed as a credit institution and subject to the Banking Act with the } \\
\text { restriction to offer CCP activities. Eurex has to meet the requirements of the } \\
\text { CRD. It is also subject to the requirements on large exposures and million } \\
\text { euro loan reporting, and liquidity regulation. The Banking Act does not } \\
\text { contains issues specific to CCPs activities, although BaFin has been using the } \\
\text { overall risk management provision (Article 25A) to require Eurex to meet the } \\
\text { CPSS/IOSCO recommendations. }\end{array}$ \\
\hline
\end{tabular}


Eurex authorization as a $\mathrm{ROCH}$ is governed by the United Kingdom law (Financial Services and Markets Acts 2000), its business in the United States is governed by United States law (Securities Exchange Act) with temporary exemptions in connection with CDS clearing, and its business in Switzerland is governed by Swiss law (Financial Market Supervision Act).

BaFin has six staff involved in regulating and overseeing clearing and settlement activities. It can also rely on additional staff from the banking supervisory department. The Bundesbank has 11 staff dealing with payment, clearing and securities settlement systems oversight (of which 5 oversee clearing and settlement activities). The BaFin regulator staff (but not the Bundesbank oversight staff) may accompany the banking supervisory staff carrying out onsite inspection. In addition,, the banking supervisory staff carrying out onsite inspection can be assigned to check some clearing aspects of Eurex clearing.

\section{Definition and disclosure of objectives of central banks and securities regulators (Q2)}

BaFin does not have any written materials that clearly disclose its objectives and roles in the field of CCPs, although some information has been given during its meetings with Eurex. The objectives and policies of the Bundesbank are clearly disclosed in several publications, including annual reports, and speeches by senior management.

By using its banking supervisory authorities, BaFin and Bundesbank have sufficient legal capacity (German Banking Act, Section 3 of the Bundesbank Act, Article 105 (2) of the EC Treaty, Article 3 and 22 ESCB-Statute) to carry out effective regulation and oversight.

Timely provision of oversight information to relevant authorities (Q3).

Eurex is not required to send proposed changes to its clearing conditions to BaFin. Authorized as a credit institution, Eurex however needs to report to BaFin and the Bundesbank on a regular basis (yearly, half-yearly, quarterly, monthly, or weekly), and on an ad hoc basis if necessary. Also, some organizational changes (new Executive Board or Supervisory Board Members, changes in participations - if any) need to be reported or even approval need to be requested on a case-by-case basis.

(a)BaFin and the Bundesbank information requirements: As home regulator, information requirements of BaFin and the Bundesbank are regulated within the Banking Law. However, this is a standardized reporting requirement aimed at covering banking activities and some items may cover Eurex activities. There are no specific reporting requirements for Eurex CCP activities.

(b) The United Kingdom FSA information requirements: Eurex informs the FSA in advance of any plans to alter the governing law of its rules, procedures, and membership agreements. Furthermore, weekly stress and back testing reports, monthly financial resource reports as well as annual reports are provided to the FSA.

(c) United States CFTC information requirements: Eurex needs to inform the CFTC about any material change in the information provided in the request for the MCO status, including information on risk management and the change agreements with regard to the exchange of information between the regulators. 
(d) United States SEC information requirements: Eurex has to inform the SEC in advance of any plans to alter Eurex rules, procedures, and membership agreements. Furthermore, Eurex reports on a bi-weekly basis stress and back testing, and monthly on disciplinary actions. It is also obliged to report participants' defaults. Any material rule changes, outages and changes in risk management have to be reported in a timely manner. In general, annual talks and discussions with the regulators take place due to the Supervisory Review and Evaluation Process (SREP). Moreover, BaFin and the Bundesbank have the mandate to request any information or to conduct any ad-hoc onsite inspections.

Domestic and cross-border cooperation (Q4)

The general conditions for domestic cooperation are laid down in a guideline for the cooperation between BaFin and Deutsche Bundesbank. This "guideline on carrying out and ensuring the quality of the ongoing monitoring of credit and financial services institutions by the Deutsche Bundesbank of $21^{\text {st }}$ of February 2008 (Supervision Guideline)" is publicly available in the internet: http://ww2.bafin.de/sdtf/xls/supervision guideline.pdf

The aforementioned supervision guideline also supports the targets of the guideline issued by the Central European Banking Supervisors (CEBS).

BaFin and Deutsche Bundesbank are actively involved and cooperate closely in developing European and international standards and principles as the "ESCB/CESR Recommendations for Central Counterparties in the European Union" and the "CPSS/IOSCO Recommendations for Central Counterparties." Both BaFin and Bundesbank review Eurex self assessments against these recommendations.

As the home regulators BaFin and the Bundesbank have the lead in supervision. BaFin and Bundesbank have formal relationships (memorandums of understanding $(\mathrm{MOU})$ ) with the other regulators.

Assessment Partly Observed

Comments

Eurex is regulated and supervised as a bank, and all regulatory requirements are related to banking activities. There is no special regulatory regime that covers Eurex CCP business. Both BaFin's and the Bundesbank's mandate to regulate, supervise and oversee Eurex is based on its banking status.

Furthermore, the Bundesbank does not have the legal basis to oversee Eurex as a financial market infrastructure.

Given the intensive involvement of BaFin and Bundesbank in domestic and international committees, working groups and fora on clearing and settlement, the current staff is not entirely sufficient to effectively carry out regulation and oversight of clearing activities. To this end, BaFin and the Bundesbank should recruit additional staff to regulate and oversee clearing activities.

The Bundesbank should be provided with the legal mandate to oversee Eurex as a CCP. Furthermore, the Bundesbank's staff should participate in the onsite inspection of Eurex as a complementary function to BaFin's regulatory responsibility

For full compliance with this recommendation, Bafin should:

(a) Define and disclose its objectives and policies with regard to CCPs activities.

(b) Either issue new regulatory regimes dedicated to CCPs activities or 
further develop, in the Banking Law, special rules and requirements for CCPs activities.

(a) Request Eurex to consult BaFin for any material changes of its clearing conditions.

Table 3. Summary of the Detailed Assessment of the Observance of Eurex Clearing AG (Eurex) with the CPSS-IOSCO Recommendations for Central Counterparties

\begin{tabular}{|c|c|c|}
\hline Responsibility & Grading & Comments \\
\hline \multicolumn{3}{|l|}{ Legal risk } \\
\hline $\begin{array}{l}\text { 1. Central counterparties should } \\
\text { have a well-founded, clear and } \\
\text { transparent legal basis in the } \\
\text { relevant jurisdiction. }\end{array}$ & $\mathrm{O}$ & $\begin{array}{l}\text { Eurex is regulated as a credit institution with } \\
\text { a single purpose to provide clearing activity. } \\
\text { The banking law and other legislations } \\
\text { provide a sound, transparent, and } \\
\text { enforceable legal basis for each aspect of its } \\
\text { activities. } \\
\text { Eurex can change its clearing conditions } \\
\text { without prior consultation or approval by the } \\
\text { relevant regulator and overseer, although } \\
\text { Eurex does so in practice. It is } \\
\text { recommended that the relevant authorities } \\
\text { should require Eurex to consult the } \\
\text { authorities prior to deciding on any material } \\
\text { changes of its clearing conditions. This } \\
\text { procedure would achieve a higher degree of } \\
\text { legal safety, better ensure that the public } \\
\text { interest is taken into account, and increase } \\
\text { impartiality vis-à-vis its participants. }\end{array}$ \\
\hline \multicolumn{3}{|l|}{ Participation requirement } \\
\hline $\begin{array}{l}\text { 2. A CCP should require } \\
\text { participants to have sufficient } \\
\text { financial resources and robust } \\
\text { operational capacity to meet } \\
\text { obligations arising from } \\
\text { participation in the CCP. A CCP } \\
\text { should have procedures in place } \\
\text { to monitor that participation } \\
\text { requirements are met in an on- } \\
\text { going basis. A CCP's } \\
\text { participation requirements } \\
\text { should be objectives, publicly } \\
\text { disclosed, and permit fair and } \\
\text { open access. }\end{array}$ & $\mathrm{O}$ & $\begin{array}{l}\text { Eurex has adequate financial and technical } \\
\text { requirements for participants, which are } \\
\text { based on the types of membership and the } \\
\text { products and services that the member will } \\
\text { use. In particular, a full member must be } \\
\text { regulated by the relevant authorities, meet } \\
\text { adequate minimum capital, contribute to the } \\
\text { clearing fund, have qualified staff and the } \\
\text { meet the minimum level of technical } \\
\text { capability including network communication, } \\
\text { and establish appropriate settlement } \\
\text { arrangement. }\end{array}$ \\
\hline $\begin{array}{l}\text { Measurement and } \\
\text { management of credit } \\
\text { exposures }\end{array}$ & & \\
\hline
\end{tabular}




\begin{tabular}{|c|c|c|}
\hline Responsibility & Grading & Comments \\
\hline $\begin{array}{l}\text { 3. A CCP should measure its } \\
\text { credit exposure to its participants } \\
\text { at least once a day. Through } \\
\text { margin requirements, other risk } \\
\text { control mechanisms or a } \\
\text { combination of both, a CCP } \\
\text { should limit its exposure to } \\
\text { potential losses from defaults of } \\
\text { its participants in normal market } \\
\text { conditions so that the operation } \\
\text { of the CCP would not be } \\
\text { disrupted and non-defaulting } \\
\text { participants would not be } \\
\text { exposed to losses that they } \\
\text { cannot anticipate or control. }\end{array}$ & $\mathrm{O}$ & $\begin{array}{l}\text { Eurex has a comprehensive and adequate } \\
\text { risk management framework composed of } \\
\text { objectives, measures, and tools defined and } \\
\text { implemented at the level of Eurex entity and } \\
\text { DBG. This framework is reviewed and } \\
\text { assessed on a regular basis. Eurex employs } \\
\text { different tools to limit its exposures to } \\
\text { potential losses from defaulting participants, } \\
\text { including capital requirement, margin } \\
\text { requirement, contribution to clearing fund, } \\
\text { and employs other risk control mechanisms. } \\
\text { In addition, intraday risk controls are in place } \\
\text { to safeguard and strengthen the lines of } \\
\text { defense of Eurex and thus ensuring its } \\
\text { continuous integrity for the markets cleared } \\
\text { by Eurex. }\end{array}$ \\
\hline \multicolumn{3}{|l|}{ Margin requirements } \\
\hline $\begin{array}{l}\text { 4. If a CCP relies on margin } \\
\text { requirements to limit its credit } \\
\text { exposures to participants, these } \\
\text { requirements should be } \\
\text { sufficient to cover potential } \\
\text { exposures in normal market } \\
\text { conditions. The models and } \\
\text { parameters used in setting } \\
\text { margin requirements should be } \\
\text { risk-based and reviewed } \\
\text { regularly. }\end{array}$ & 0 & $\begin{array}{l}\text { Eurex relies on initial and variation margin } \\
\text { requirements to limit its credit exposures to } \\
\text { participants. The margin requirements are } \\
\text { met through cash and eligible securities } \\
\text { deposited in regulated entities. Eurex tests } \\
\text { regularly the risk-based model on which the } \\
\text { margin requirements calculation is based. } \\
\text { The margin model and its parameters are } \\
\text { regularly validated internally and by the } \\
\text { authorities. The parameters and the } \\
\text { assumptions that are used in the models are } \\
\text { validated in daily, weekly monthly or quarterly } \\
\text { reviews depending on parameter type. } \\
\text { Market participants are informed on the } \\
\text { assumptions, parameters, and scenarios. }\end{array}$ \\
\hline \multicolumn{3}{|l|}{ Financial resources } \\
\hline $\begin{array}{l}\text { 5. A CCP should maintain } \\
\text { sufficient financial resources to } \\
\text { withstand, at a minimum, the } \\
\text { default of a participant to which it } \\
\text { has the largest exposure in } \\
\text { extreme but plausible market } \\
\text { conditions. }\end{array}$ & $\mathrm{O}$ & $\begin{array}{l}\text { By using a comprehensive risk management } \\
\text { framework, Eurex has defined its financial } \\
\text { resources needed to withstand the default of } \\
\text { three participants with the largest exposures } \\
\text { in extreme, but plausible market conditions. } \\
\text { Eurex performs daily stress testing with } \\
\text { extreme, but plausible market conditions, } \\
\text { which can also be run on intraday basis } \\
\text { when needed. } \\
\text { As a CCP, Eurex has access to an intraday } \\
\text { credit facility of the Eurosystem in line with } \\
\text { the TARGET2 Guideline. As a credit } \\
\text { institution, it is also eligible to receive } \\
\text { emergency liquidity assistance from the } \\
\text { Bundesbank. Cash margins placed by } \\
\text { clearing members are almost all invested }\end{array}$ \\
\hline
\end{tabular}




\begin{tabular}{|c|c|c|}
\hline Responsibility & Grading & Comments \\
\hline & & $\begin{array}{l}\text { overnight and are thus to be classified as } \\
\text { immediately available. }\end{array}$ \\
\hline \multicolumn{3}{|l|}{ Default procedures } \\
\hline $\begin{array}{l}\text { 6. A CCP default procedures } \\
\text { should be clearly stated, and } \\
\text { should ensure that the CCP can } \\
\text { take timely action to contain } \\
\text { losses and liquidity pressure and } \\
\text { to continue meeting its } \\
\text { obligations. Key aspects of the } \\
\text { default procedures should be } \\
\text { publicly available. }\end{array}$ & 0 & $\begin{array}{l}\text { Eurex default rules and procedures are } \\
\text { clearly stated in its clearing conditions, which } \\
\text { allow Eurex to transfer customers' positions } \\
\text { to another clearing member, close out, and } \\
\text { settle the defaulting member's open } \\
\text { positions. Eurex also has the right to assign } \\
\text { the remaining positions pro rata to the non- } \\
\text { defaulting clearing members. } \\
\text { The German legislative framework provides a } \\
\text { high degree of assurance with regard to the } \\
\text { enforceability of default procedures. } \\
\text { However, at present, the legal basis to } \\
\text { separate the customer's collaterals from } \\
\text { those of the clearing member is not entirely } \\
\text { robust from a legal viewpoint. } \\
\text { It is not certain whether German insolvency } \\
\text { law fully supports the transfer of customer } \\
\text { positions and collateral. In case of } \\
\text { insolvency of a clearing member, the } \\
\text { Insolvency Act provides for close-out netting } \\
\text { of customer positions. As a consequence, } \\
\text { positions are transformed into a single } \\
\text { payment obligation and cannot be } \\
\text { transferred to another clearing member any } \\
\text { more. The German parliament (Bundestag) } \\
\text { currently discusses an amendment to the } \\
\text { Insolvency Act that would allow the CCP to } \\
\text { transfer customer positions and collateral to } \\
\text { another clearing member in case of } \\
\text { insolvency of the original clearing member. } \\
\text { The transfer of customer positions and } \\
\text { collateral including support by insolvency law } \\
\text { is also provided for in the draft EMIR, which } \\
\text { would be directly applicable in Germany. }\end{array}$ \\
\hline Custody and investment risk & & \\
\hline $\begin{array}{l}\text { 7. A CCP should hold assets in } \\
\text { a manner whereby risk of loss or } \\
\text { of delay in its access to them is } \\
\text { minimized. Assets invested by a } \\
\text { CCP should be held in } \\
\text { instruments with minimal credit, } \\
\text { market and liquidity risks. }\end{array}$ & $\mathrm{O}$ & $\begin{array}{l}\text { Securities pledged to Eurex by its } \\
\text { participants are only deposited with CSDs } \\
\text { and ICSDs, which are supervised by national } \\
\text { authorities. These securities can be } \\
\text { withdrawn only with the consent of Eurex } \\
\text { clearing AG. } \\
\text { Regulations in Germany and Switzerland } \\
\text { provide an appropriate legal environment to } \\
\text { ensure access to pledged securities in the } \\
\text { case of insolvency of the clearing member. }\end{array}$ \\
\hline
\end{tabular}




\begin{tabular}{|c|c|c|}
\hline Responsibility & Grading & Comments \\
\hline & & $\begin{array}{l}\text { Eurex has in place processes and } \\
\text { specialized staff to monitor the custodian } \\
\text { banks, including daily monitoring and } \\
\text { periodical review of the custodians. Eurex } \\
\text { assesses these custodians against } \\
\text { recommendation } 12 \text { with regard to } \\
\text { accounting practices and } \\
\text { safekeeping/internal control procedures, } \\
\text { regulated, and strong financial position. }\end{array}$ \\
\hline \multicolumn{3}{|l|}{ Operational risk } \\
\hline $\begin{array}{l}\text { 8. A CCP should identify sources } \\
\text { of operational risk and minimize } \\
\text { them through the development of } \\
\text { appropriate systems, controls } \\
\text { and procedures. Systems should } \\
\text { be reliable and secure, and have } \\
\text { adequate, scalable capacity. } \\
\text { Business continuity plans should } \\
\text { allow for timely recovery of } \\
\text { operations and fulfillment of a } \\
\text { CCP's obligations. }\end{array}$ & 0 & $\begin{array}{l}\text { The Eurex risk management framework is } \\
\text { governed by policies and procedures defined } \\
\text { both at the level of Eurex and of DBG, which } \\
\text { has developed and implemented a } \\
\text { comprehensive BCM policy. This policy } \\
\text { defines the organizational roles and } \\
\text { responsibilities, and the guiding principles to } \\
\text { ensure operational resilience. } \\
\text { Eurex carries out testing of its contingency } \\
\text { plan, IT infrastructure, and communication } \\
\text { network with the majority of its participants } \\
\text { on an annual basis. } \\
\text { To ensure business continuity, there are two } \\
\text { geographically separated IT processing } \\
\text { sites. The systems are clustered between } \\
\text { the two data centers and load balanced in } \\
\text { normal operation mode with continuous full } \\
\text { data synchronization (real-time data } \\
\text { mirroring). }\end{array}$ \\
\hline \multicolumn{3}{|l|}{ Money settlements } \\
\hline $\begin{array}{l}\text { 9. A CCP should employ money } \\
\text { settlement arrangements that } \\
\text { should eliminate or strictly limit } \\
\text { its settlement bank risks, that is, } \\
\text { its credit and liquidity risk from } \\
\text { the use of banks to effect money } \\
\text { settlements with its participants. } \\
\text { Funds transfers to a CCP should } \\
\text { be final when effected. }\end{array}$ & $\mathrm{O}$ & $\begin{array}{l}\text { Eurex relies on a few banks for the } \\
\text { settlement of foreign exchange denominated } \\
\text { transactions, which exposures it to } \\
\text { settlement risk. Access to central bank } \\
\text { account would enhance the integrity of the } \\
\text { settlement process. To this end, in } 2008 \text {, } \\
\text { Eurex applied for an account with the } \\
\text { Federal Reserve Bank of New York but no } \\
\text { positive access decision has been taken } \\
\text { since then. } \\
\text { Eurex uses central bank money for a broad } \\
\text { range of products, e.g. the collections of } \\
\text { margins, the settlement of German equities, } \\
\text { and the settlement of bonds and repos. } \\
\text { Nevertheless, as most banks hold their fixed } \\
\text { income portfolios in the ICSDs (i.e. } \\
\text { Clearstream Luxembourg and Euroclear }\end{array}$ \\
\hline
\end{tabular}




\begin{tabular}{|c|c|c|}
\hline Responsibility & Grading & Comments \\
\hline & & $\begin{array}{l}\text { Bank Brussels), contracts based on these } \\
\text { fixed income securities are settled in } \\
\text { commercial bank money in those ICSDs. } \\
\text { This applies to bond and repo transactions } \\
\text { carried out on the trading platforms Eurex } \\
\text { Bonds and Eurex Repo. } \\
\text { To further reduce settlement risk, Eurex may } \\
\text { consider to settling in central bank money } \\
\text { and/or increasing the number of settlement } \\
\text { agent banks for FX currencies. }\end{array}$ \\
\hline \multicolumn{3}{|l|}{ Physical deliveries } \\
\hline $\begin{array}{l}\text { 10. A CCP should clearly state } \\
\text { its obligations with respect to } \\
\text { physical deliveries. The risks } \\
\text { from these obligations should be } \\
\text { identified and managed. }\end{array}$ & 0 & $\begin{array}{l}\text { Eurex deliveries of securities are carried out } \\
\text { in book-entry form (immobilized or } \\
\text { dematerialized) and delivery obligations are } \\
\text { fulfilled via book transfer. Eurex rules clearly } \\
\text { define the responsibilities to deliver and } \\
\text { receive securities from participants. } \\
\text { Eurex settles on a DVP basis, which takes } \\
\text { place in CSD or ICSD. All risks affecting } \\
\text { deliveries are assessed by risk management } \\
\text { in real-time. }\end{array}$ \\
\hline \multicolumn{3}{|l|}{ Risks in links between CCPs } \\
\hline $\begin{array}{l}\text { 11. CCPs that establish links } \\
\text { either cross-border or } \\
\text { domestically to clear trades } \\
\text { should evaluate the potential } \\
\text { sources of risks that can arise, } \\
\text { and ensure that the risks are } \\
\text { managed prudently on an } \\
\text { ongoing basis. There should be } \\
\text { a framework for cooperation and } \\
\text { coordination among the relevant } \\
\text { regulators and overseers. }\end{array}$ & 0 & $\begin{array}{l}\text { Eurex has currently one link with the ECC. } \\
\text { There is a clearing link agreement between } \\
\text { Eurex and ECC that define the rights and } \\
\text { obligations between Eurex and ECC. Eurex } \\
\text { has specific rules and procedures for linked } \\
\text { CCP. Before entering into a link, risks are } \\
\text { evaluated (including due diligence or other } \\
\text { analysis/measures as seen fit) according to } \\
\text { a specific link methodology. Once a link is } \\
\text { implemented and is operational, the risks } \\
\text { associated with the link are evaluated daily. }\end{array}$ \\
\hline \multicolumn{3}{|l|}{ Efficiency } \\
\hline $\begin{array}{l}\text { 12. While maintaining safe and } \\
\text { secure operations, CCPs should } \\
\text { be cost-effective in meeting the } \\
\text { requirements of participants. }\end{array}$ & 0 & $\begin{array}{l}\text { Eurex has in place procedures to control its } \\
\text { operational costs. All budgets are reviewed } \\
\text { and approved by management. All pricing } \\
\text { levels are repeatedly reviewed. Eurex } \\
\text { perform periodic benchmarking studies with } \\
\text { comparable CCPs in other European } \\
\text { countries to assess its costs and fees. Eurex } \\
\text { provides rebates to participants when their } \\
\text { volume of transactions exceeds some } \\
\text { specified thresholds. An ongoing profit and } \\
\text { loss analysis is conducted and the outcome } \\
\text { is provided to the Executive Board of Eurex. } \\
\text { Eurex applies higher prices to clear OTC } \\
\text { transactions compared to exchange-traded }\end{array}$ \\
\hline
\end{tabular}




\begin{tabular}{|c|c|c|}
\hline Responsibility & Grading & Comments \\
\hline & & $\begin{array}{l}\text { transactions. Eurex's argument for this policy } \\
\text { is to promote the move of OTC transactions } \\
\text { to the exchange. Although such a policy has } \\
\text { merits, it is possible that there is a } \\
\text { preferential treatment to clear traded } \\
\text { transactions compared to the clearing of } \\
\text { OTC transactions. }\end{array}$ \\
\hline \multicolumn{3}{|l|}{ Governance } \\
\hline $\begin{array}{l}\text { 13. Governance arrangements } \\
\text { for a CCP should be clear and } \\
\text { transparent to fulfill public } \\
\text { interest requirements and to } \\
\text { support the objectives of owners } \\
\text { and participants. In particular, } \\
\text { they should promote the } \\
\text { effectiveness of a CCP's risk } \\
\text { management procedures. }\end{array}$ & 0 & $\begin{array}{l}\text { Eurex governance arrangements are clear } \\
\text { and transparent, and publicly available via } \\
\text { the Eurex website. These arrangements also } \\
\text { reflect the public interest requirements and } \\
\text { support the objectives of owners and } \\
\text { participants. } \\
\text { Eurex should increase the number of } \\
\text { independent board members taking into } \\
\text { account the interests of small and medium- } \\
\text { sized clearing members. } \\
\text { Due to the crucial role of Eurex in the } \\
\text { German financial market, BaFin may explore } \\
\text { the possibility to define explicit public interest } \\
\text { objective to Eurex such as to facilitate } \\
\text { prompt, efficient, and sound clearing of } \\
\text { securities transactions. }\end{array}$ \\
\hline \multicolumn{3}{|l|}{ Transparency } \\
\hline $\begin{array}{l}\text { 14. A CCP should provide } \\
\text { market participants with sufficient } \\
\text { information for them to identify } \\
\text { and evaluate accurately the } \\
\text { costs and risks associated with } \\
\text { using its services. }\end{array}$ & $\mathrm{O}$ & $\begin{array}{l}\text { Eurex discloses to its clearing members and } \\
\text { other market participants its rules, } \\
\text { procedures, and policies on its website. } \\
\text { These rules cover, among other things, } \\
\text { governance issues, procedures for handling } \\
\text { risks, the rights and obligations of } \\
\text { participants, and the costs of using its } \\
\text { services. } \\
\text { Eurex also discloses to its members } \\
\text { information on the used risk methodologies } \\
\text { (i.e., RBM; scenario based matrix approach; } \\
\text { and historical simulation), risk parameters, } \\
\text { and other calculations (e.g., detailed risk } \\
\text { scenario calculations). Assessment of risks } \\
\text { and costs are publicly distributed on a } \\
\text { periodic basis (for example, parameters; } \\
\text { margin; and haircuts). }\end{array}$ \\
\hline Regulation and oversight & & \\
\hline
\end{tabular}




\begin{tabular}{|c|c|c|}
\hline Responsibility & Grading & Comments \\
\hline $\begin{array}{l}\text { 15. A CCP should be subject to } \\
\text { transparent and effective } \\
\text { regulation and oversight. In both } \\
\text { a domestic and an international } \\
\text { context, central banks and } \\
\text { securities regulators should co- } \\
\text { operate with each other and with } \\
\text { other relevant authorities. }\end{array}$ & $\mathrm{PO}$ & $\begin{array}{l}\text { Eurex is regulated and supervised as a } \\
\text { bank, and all regulatory requirements are } \\
\text { related to banking activities. There is no } \\
\text { special regulatory regime that covers Eurex' } \\
\text { CCP business. Both BaFin's and } \\
\text { Bundesbank's mandates to regulate, } \\
\text { supervise and oversee Eurex is based on its } \\
\text { banking status. Furthermore, the } \\
\text { Bundesbank does not have the legal basis to } \\
\text { oversee Eurex as financial market } \\
\text { infrastructure. } \\
\text { The Bundesbank should be provided with } \\
\text { the legal mandate to oversee Eurex as a } \\
\text { CCP. Further, the Bundesbank's staff should } \\
\text { participate in the onsite inspection of Eurex } \\
\text { as a complementary to BaFin's regulatory } \\
\text { responsibility. } \\
\text { Given the intensive involvement of BaFin } \\
\text { and Bundesbank in domestic and } \\
\text { international committees, working groups } \\
\text { and fora on clearing and settlement, the } \\
\text { current staff is not entirely sufficient to } \\
\text { effective carry out regulation and oversight of } \\
\text { clearing activities. To this end, BaFin and } \\
\text { Bundesbank should recruit additional staff to } \\
\text { regulate and oversee clearing activities. } \\
\text { For the full compliance with this } \\
\text { recommendation: } \\
\text { a. BaFin should define and disclose its } \\
\text { objectives and policies with regard to } \\
\text { CCPs activities. } \\
\text { b. BaFin should either issue a new } \\
\text { regulatory regime dedicated to CCP } \\
\text { activities, or further develop, in the } \\
\text { Banking Law, special rules and } \\
\text { requirements for CCP activities. } \\
\text { c. BaFin should request Eurex to consult } \\
\text { BaFin for any material changes of its } \\
\text { clearing conditions. }\end{array}$ \\
\hline
\end{tabular}


Table 4. Actions to Improve Compliance

\begin{tabular}{|c|c|}
\hline $\begin{array}{l}\text { Reference } \\
\text { Recommendation }\end{array}$ & Recommended Action \\
\hline $\begin{array}{l}\text { Recommendation 1: } \\
\text { Legal risk }\end{array}$ & $\begin{array}{l}\text { It is recommended that the relevant authorities should require } \\
\text { Eurex to consult the authorities in advance for any material } \\
\text { changes of its clearing conditions. This procedure would achieve a } \\
\text { higher degree of legal safety, better ensure that the public interest } \\
\text { is taken into account, and increase impartiality vis-à-vis its } \\
\text { participants. }\end{array}$ \\
\hline $\begin{array}{l}\text { Recommendation 15: } \\
\text { Regulation and oversight }\end{array}$ & $\begin{array}{l}\text { BaFin should clearly define and disclose its objectives and policies } \\
\text { with regard to CCPs activities. } \\
\text { BaFin should either issue a new regulatory regime dedicated to } \\
\text { CCPs activities, or further develop, in the Banking Law, specific } \\
\text { rules and requirements for CCPs activities. } \\
\text { BaFin should request Eurex to consult BaFin for any material } \\
\text { changes of its clearing conditions. } \\
\text { The Bundesbank should be provided with the legal mandate to } \\
\text { oversee Eurex as a CCP. Further, the Bundesbank's staff should } \\
\text { participate in the onsite inspection of Eurex as a complementary } \\
\text { function to BaFin's regulatory responsibility } \\
\text { BaFin and the Bundesbank should recruit additional staff to carry } \\
\text { out the regulation and oversight of clearing activities more } \\
\text { effectively. }\end{array}$ \\
\hline
\end{tabular}

Table 5. Further Recommended Actions

\begin{tabular}{|l|l|}
\hline $\begin{array}{l}\text { Reference } \\
\text { Recommendation }\end{array}$ & Recommended Action \\
\hline $\begin{array}{l}\text { Recommendation 6: } \\
\text { Default procedures }\end{array}$ & $\begin{array}{l}\text { At present, the legal basis to ensure portability of a } \\
\text { customer's collaterals is not entirely robust from a legal } \\
\text { viewpoint. In the case of default, there is a potential risk } \\
\text { that the customer's holdings cannot be ported to another } \\
\text { clearing member. However, an amendment of Article 104a } \\
\text { of the insolvency law to eliminate this potential risk is } \\
\text { currently under discussion in Bundestag. }\end{array}$ \\
\hline $\begin{array}{l}\text { Recommendation 9: } \\
\text { Money settlements }\end{array}$ & $\begin{array}{l}\text { To further reduce settlement risk, Eurex may consider to } \\
\text { settling in central bank money and/or increasing the number of } \\
\text { settlement agent banks for FX currencies. }\end{array}$ \\
\hline $\begin{array}{l}\text { Recommendation 12: } \\
\text { Efficiency }\end{array}$ & $\begin{array}{l}\text { Eurex should make public its differentiated price policy with } \\
\text { regard to clearing non-traded transactions as a part of the } \\
\text { general policy to encourage movement of these transactions to } \\
\text { the exchange. }\end{array}$ \\
\hline
\end{tabular}




\begin{tabular}{|l|l|}
\hline $\begin{array}{l}\text { Reference } \\
\text { Recommendation } \\
\text { Gecommendation 13: }\end{array}$ & Recommended Action \\
\hline $\begin{array}{l}\text { Eurex should increase the number of independent board } \\
\text { members taking into account the interests of small and } \\
\text { medium-size clearing members. }\end{array}$ \\
$\begin{array}{l}\text { Due to the crucial role of Eurex in the German financial market, } \\
\text { BaFin should explore the possibility of defining an explicit public } \\
\text { interest objective to Eurex, such as facilitating prompt, efficient } \\
\text { and sound clearing of securities transactions. }\end{array}$ \\
\hline
\end{tabular}

\section{Authorities' response to the assessment}

17. In Recommendation 13, the IMF suggests to increase the number of independent board members taking into account the interests of small and medium-sized members. However, Eurex has to take into account that in Germany, the members of the supervisory board are elected by the shareholders only and Eurex cannot influence their decision. 